\title{
Synthesis and in Vivo Biological Evaluation of Ga-68- Labeled Carbonic Anhydrase IX Targeting Small Molecules for Positron Emission Tomography
}

Citation for published version (APA):

Sneddon, D., Niemans, R., Bauwens, M., Yaromina, A., van Kuijk, S. J. A., Lieuwes, N. G., Biemans, R., Pooters, I., Pellegrini, P. A., Lengkeek, N. A., Greguric, I., Tonissen, K. F., Supuran, C. T., Lambin, P., Dubois, L., \& Poulsen, S-A. (2016). Synthesis and in Vivo Biological Evaluation of Ga-68-Labeled Carbonic Anhydrase IX Targeting Small Molecules for Positron Emission Tomography. Journal of Medicinal Chemistry, 59(13), 6431-6443. https://doi.org/10.1021/acs.jmedchem.6b00623

Document status and date:

Published: 14/07/2016

DOI:

10.1021/acs.jmedchem.6b00623

Document Version:

Publisher's PDF, also known as Version of record

Document license:

Taverne

Please check the document version of this publication:

- A submitted manuscript is the version of the article upon submission and before peer-review. There can be important differences between the submitted version and the official published version of record.

People interested in the research are advised to contact the author for the final version of the publication, or visit the DOI to the publisher's website.

- The final author version and the galley proof are versions of the publication after peer review.

- The final published version features the final layout of the paper including the volume, issue and page numbers.

Link to publication

\footnotetext{
General rights rights.

- You may freely distribute the URL identifying the publication in the public portal. please follow below link for the End User Agreement:

www.umlib.nl/taverne-license

Take down policy

If you believe that this document breaches copyright please contact us at:

repository@maastrichtuniversity.nl

providing details and we will investigate your claim.
}

Copyright and moral rights for the publications made accessible in the public portal are retained by the authors and/or other copyright owners and it is a condition of accessing publications that users recognise and abide by the legal requirements associated with these

- Users may download and print one copy of any publication from the public portal for the purpose of private study or research.

- You may not further distribute the material or use it for any profit-making activity or commercial gain

If the publication is distributed under the terms of Article $25 \mathrm{fa}$ of the Dutch Copyright Act, indicated by the "Taverne" license above, 


\section{Journal of \\ Medicinal Chemistry}

\section{Synthesis and in Vivo Biological Evaluation of ${ }^{68} \mathrm{Ga}$-Labeled Carbonic Anhydrase IX Targeting Small Molecules for Positron Emission Tomography}

Deborah Sneddon, ${ }^{\dagger, \#}$ Raymon Niemans, ${ }^{\ddagger, \#}$ Matthias Bauwens, ${ }^{\S}$ Ala Yaromina, ${ }^{\ddagger}$ Simon J. A. van Kuijk, Natasja G. Lieuwes, ${ }^{\ddagger}$ Rianne Biemans, " Ivo Pooters, ${ }^{\ddagger}$ Paul A. Pellegrini, " Nigel A. Lengkeek," Ivan Greguric,, Kathryn F. Tonissen, ${ }^{\dagger}$ Claudiu T. Supuran, ${ }^{\perp}$ Philippe Lambin, ${ }^{\ddagger}$ Ludwig Dubois, ${ }^{*}$, and Sally-Ann Poulsen* ${ }^{\dagger}$

${ }^{\dagger}$ Eskitis Institute for Drug Discovery, Griffith University, Nathan, Queensland 4111, Australia

${ }^{\ddagger}$ Maastricht Radiation Oncology (MAASTRO Lab), GROW - School for Oncology and Developmental Biology, Maastricht University, Medical Centre, 6200 MD Maastricht, The Netherlands

${ }^{\S}$ Departments of Radiology and Nuclear Medicine, Maastricht University Medical Centre, 6202 AZ Maastricht, The Netherlands

"LifeSciences Division, Australian Nuclear Science and Technology Organisation (ANSTO), Locked Bag 2001, Kirrawee DC, New South Wales 2232, Australia

${ }^{\perp}$ Dipartimento Neurofarba, Sezione di Scienze Farmaceutiche, Polo Scientifico, Università degli Studi di Firenze, 50019 Sesto Fiorentino, Italy

\section{Supporting Information}

ABSTRACT: Tumor hypoxia contributes resistance to chemo- and radiotherapy, while oxygenated tumors are sensitive to these treatments. The indirect detection of hypoxic tumors is possible by targeting carbonic anhydrase IX (CA IX), an enzyme overexpressed in hypoxic tumors, with sulfonamide-based imaging agents. In this study, we present the design and synthesis of novel gallium-radiolabeled small-molecule sulfonamides targeting CA IX. The compounds display favorable in vivo pharmacokinetics and stability. We demonstrate that our lead compound, $\left[{ }^{68} \mathrm{Ga}\right]-2$, discriminates CA IX-expressing tumors in vivo in a mouse xenograft model using positron emission tomography (PET). This compound

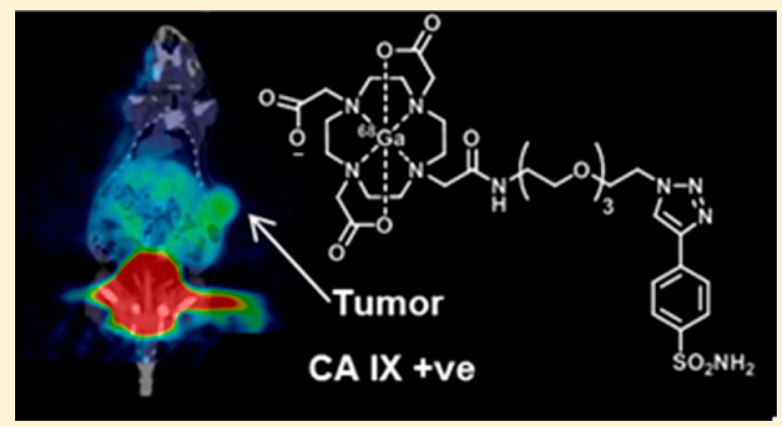
shows specific tumor accumulation and low uptake in blood and clears intact to the urine. These findings were reproduced in a second study using PET/computed tomography. Small molecules investigated to date utilizing ${ }^{68} \mathrm{Ga}$ for preclinical CA IX imaging are scarce, and this is one of the first effective ${ }^{68} \mathrm{Ga}$ compounds reported for PET imaging of CA IX.

\section{INTRODUCTION}

Molecular imaging with positron emission tomography (PET) has had a profound impact on primary diagnosis, management, therapy monitoring, and prognosis in cancer; it is noninvasive and provides personalized care to patients by informing treatment decisions and evaluating treatment response. Hypoxia (low oxygen concentration) is a characteristic feature of solid tumors. Hypoxic cells co-opt adaptive mechanisms to switch to a glycolytic metabolism, promote cell proliferation, evade immune attack, induce angiogenesis, invade, and metastasize. ${ }^{1}$ Tumor hypoxia is a negative prognostic factor associated with a more aggressive phenotype, specifically with resistance to chemo- and radiotherapy. For example, up to a 3fold higher radiation dose is needed to achieve the same level of tumor cell death in hypoxic tumors as in oxygenated tumors. ${ }^{2}$ The implementation of a hypoxia-guided clinical management strategy, such as hypoxia radiation sensitizers (e.g., nimor- $\operatorname{azole}^{3}$ ) or hypoxia-specific cytotoxic therapy (e.g., TH-302; Figure $1 \mathrm{~A}),{ }^{4}$ to those patients most likely to benefit is currently not possible, as there is no established method in routine clinical practice that is (i) noninvasive, (ii) routine to prepare, and (iii) indicative of the hypoxic cell population. ${ }^{2}$ Most current methods to detect hypoxia are invasive (e.g., require surgery) and are subject to technical issues that cause sampling errors.

Small-molecule molecular probes for imaging of hypoxia with PET may be split into two broad categories: "direct" and "indirect" imaging probes. Nitroimidazoles are direct imaging probes for the detection of hypoxia with PET, with one compound, ${ }^{18} \mathrm{~F}$-fluoromisonidazole $\left({ }^{18} \mathrm{~F}\right.$-FMISO) in limited clinical use. ${ }^{5}$ Second- and third-generation nitroimidazoles, ${ }^{18} \mathrm{~F}$ -

Received: April 21, 2016

Published: June 20, 2016 
A

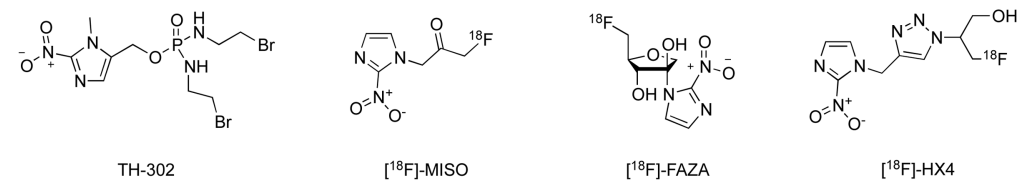

B
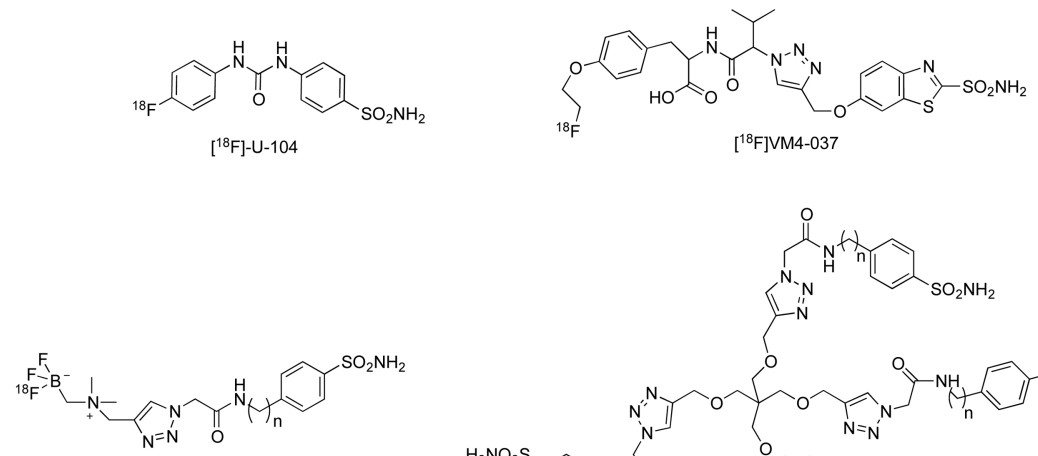

$\left[{ }^{18} \mathrm{~F}_{\mathrm{AmBF}}-\mathrm{ABS}(\mathrm{n}=0)\right.$ ${ }^{18} \mathrm{~F}^{-A_{A m B F}}{ }_{3}$-AEBS $(n=2)$
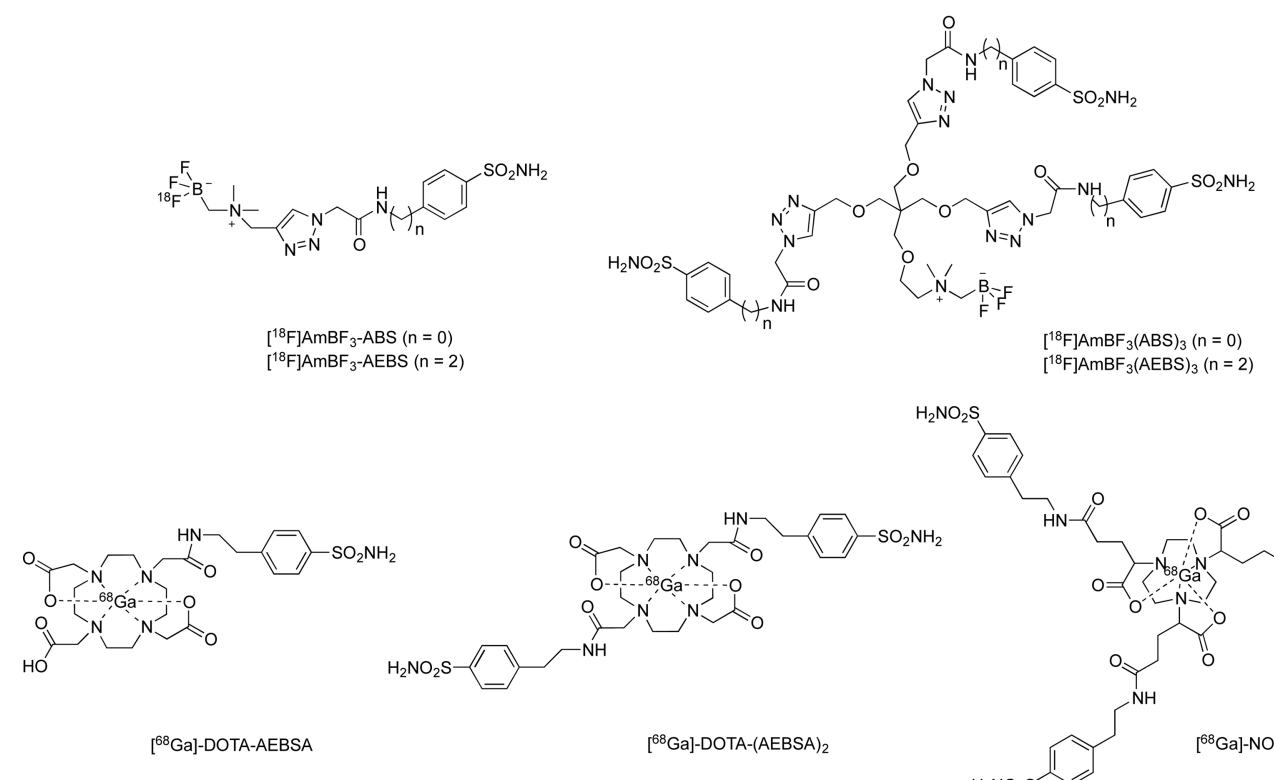

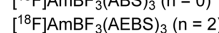

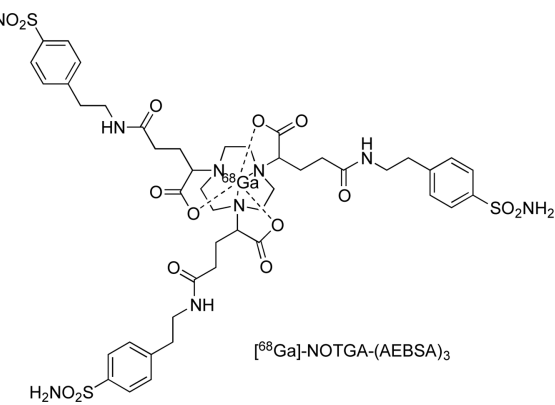

Figure 1. (A) Nitroimidazole hypoxia-targeted cytotoxic drug TH-302 and small-molecule nitroimidazole PET imaging agents for hypoxia: ${ }^{18} \mathrm{~F}-$ MISO, ${ }^{18}$ F-FAZA, and ${ }^{18} \mathrm{~F}-\mathrm{HX} 4$. (B) Small-molecule primary sulfonamides investigated in animal models for CA IX imaging with PET. $25-28$

FAZA and ${ }^{18} \mathrm{~F}-\mathrm{HX} 4$, respectively, have been shown by us to address the pharmacokinetic (PK) problems of ${ }^{18} \mathrm{~F}-\mathrm{FMISO}$ (slow tumor-specific accumulation and nonspecific washout), but better probes for hypoxia are still required. ${ }^{5-8}$

A critical cellular response to hypoxia is the stabilization and activation of the transcription factor hypoxia inducible factor- $1 \alpha$ (HIF-1 $\alpha$ ). HIF-1 $\alpha$ regulates the expression of genes required for survival under hypoxia. In principle, the gene products may be used as targets for imaging of tumor hypoxia with indirect probes and bypass the drawbacks associated with nitroimidazole probes. ${ }^{9}$ Carbonic anhydrase IX (CA IX) is one of the most highly induced HIF-1 $\alpha$-responsive genes and is proposed as the "gold standard" endogenous marker of cellular hypoxia. ${ }^{10-13}$ CA IX expression is a negative prognostic factor in several types of cancer. ${ }^{14}$ Additionally CA IX (over)expression is thought to predict the therapeutic effect of CA IXtargeting anticancer therapies. CA IX is overexpressed and sustained in many solid tumors, including breast, brain (glioblastoma), clear cell renal, colorectal, head and neck, bladder, and non-small cell lung carcinomas, but expression in normal tissues is restricted to the stomach and gastrointestinal tract. $^{10,15}$

CA IX is a transmembrane zinc metalloenzyme that catalyzes the reversible hydration of $\mathrm{CO}_{2}$ to give $\mathrm{HCO}_{3}{ }^{-}$and $\mathrm{H}^{+}$, enabling the tumor to regulate $\mathrm{pH}$, allowing its spread and survival. $^{12,13,16-20}$ Expression of CA IX is commonly used as a histologic marker of tissue hypoxia, with detection using $\mathrm{M} 75^{18}$ or G250, ${ }^{21}$ two different monoclonal antibodies specific for CA IX. There are several antibody- and antibody-fragment-based imaging agents with in vivo data that indirectly target hypoxic tumors by binding to CA IX. ${ }^{22,23}$

Our groups have shown that small-molecule sulfonamides are able to discriminate oxygen levels in tissues and bind preferentially to CA IX only in hypoxic cells, while CA IXtargeting antibodies also bind upon reoxygenation. ${ }^{24}$ Therefore, our attention has turned to small molecules to develop radiopharmaceuticals to detect CA IX-positive tumors with PET. To date, very few small molecules that incorporate a primary sulfonamide functional group, which is required for tight binding to the active site zinc in CA IX (see examples in Figure 1), have been developed and tested for CA IX imaging with PET in vivo. ${ }^{25-29}$ Compound $\left[{ }^{18} \mathrm{~F}\right] \mathrm{U}-104$ proved to be ineffective because of poor PK. ${ }^{28}\left[{ }^{18} \mathrm{~F}\right] \mathrm{VM} 4-037$ was found to be safe for use in healthy volunteers, ${ }^{25}$ but no CA IX-dependent uptake was found in vivo. ${ }^{30,31}$ In a recent phase-II pilot study of two patients with clear cell renal cell carcinoma (RCC) primary tumors with this agent, uptake was observed in both healthy and cancerous kidney as well as metastases, and CA IX selectivity was not confirmed, ${ }^{32}$ limiting the use of this imaging agent in RCC. The trivalent sulfonamide compounds $\left[{ }^{18} \mathrm{~F}\right]$ $\mathrm{AmBF}_{3}-(\mathrm{ABS})_{3}$ and $\left[{ }^{18} \mathrm{~F}\right] \mathrm{AmBF}_{3}-(\mathrm{AEBS})_{3}$ have demonstrated imaging efficacy in vivo enabling tumor visualization with a 

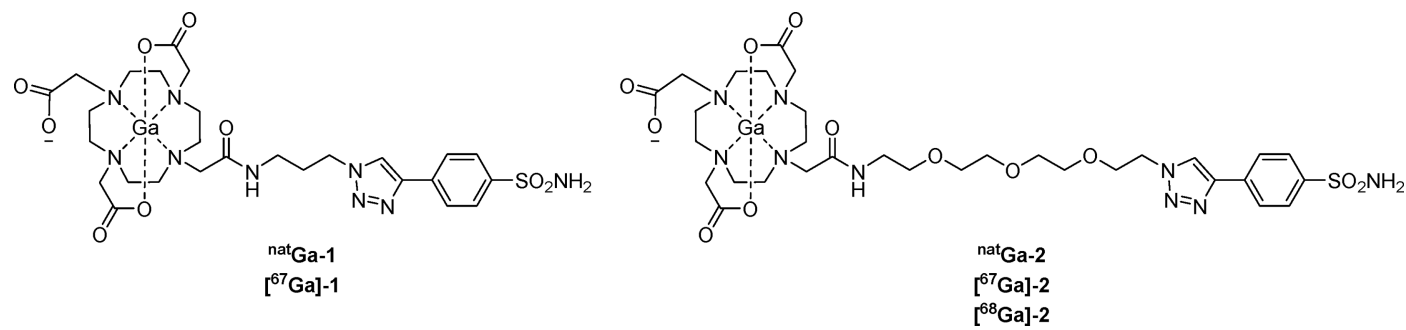

Figure 2. Target [sulfonamide]-[triazole linker]-[DOTA] compounds for use as CA IX imaging agents.

Scheme 1. Synthesis of ${ }^{\text {nat }} \mathrm{Ga}-1^{a}$<smiles>NCCCCCCCCC(=O)Br</smiles><smiles>[B]CC(=O)NCCCN</smiles>

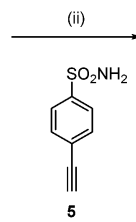
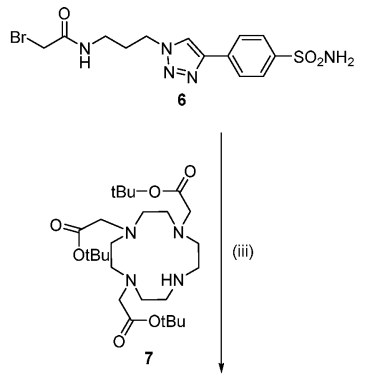
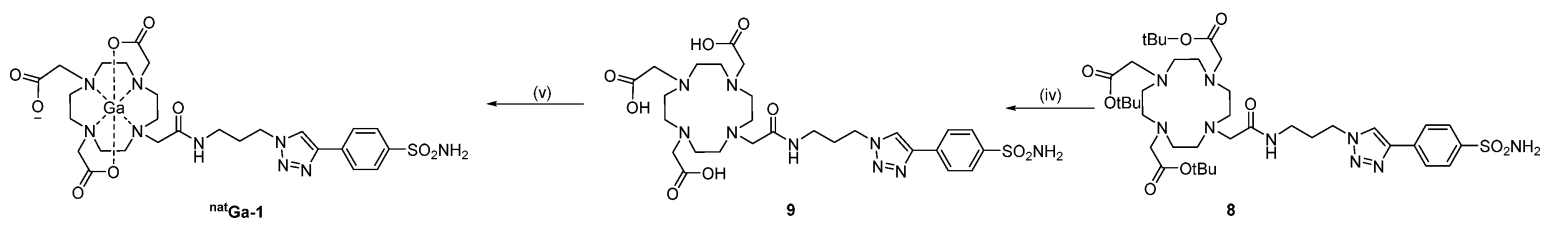

${ }^{a}$ Reagents and conditions: (i) bromoacetyl bromide (3.3 equiv), $1.0 \mathrm{M}$ aqueous $\mathrm{NaOH}$ ( 3 equiv), DCM, rt, $18 \mathrm{~h}$; (ii) 5 ( 1.0 equiv), $\mathrm{CuSO} 4$ ( 0.05 equiv), sodium ascorbate (0.1 equiv), TBTA (0.05 equiv), 2:1 DMSO $/ \mathrm{H}_{2} \mathrm{O}, 45^{\circ} \mathrm{C}, 3 \mathrm{~h}$; (iii) 7 (1.2 equiv), $\mathrm{K}_{2} \mathrm{CO}_{3}$ (1.2 equiv), anhydrous MeCN, rt, $18 \mathrm{~h}$; (iv) 1:1 TFA/DCM, rt, $18 \mathrm{~h}$; (v) $\mathrm{Ga}\left(\mathrm{NO}_{3}\right)_{3} \cdot \mathrm{xH}_{2} \mathrm{O}$ (1.1 equiv), $\mathrm{H}_{2} \mathrm{O}, 80{ }^{\circ} \mathrm{C}, 2-4 \mathrm{~h}$.

respective tumor-to-blood ratio (TBR) of $3.93 \pm 1.26$ or $2.88 \pm$ 1.81 in CA IX-expressing HT-29 tumors $1 \mathrm{~h}$ after injection. Interestingly, the monovalent variants showed a TBR close to unity and hence were less effective as imaging agents. ${ }^{26}$ No discrimination between CA IX-expressing or nonexpressing tumors was shown, but preinjection of acetazolamide effectively blocked uptake of $\left[{ }^{18} \mathrm{~F}\right] \mathrm{AmBF}_{3}-(\mathrm{ABS})_{3}$ in the tumor. Recently another series of mono-, di-, and trivalent sulfonamides based on ${ }^{68} \mathrm{Ga}$-DOTA/NOTGA as the PET reporter group were tested in a CA IX-expressing HT-29 tumor xenograft, and again only the trivalent sulfonamide $\left({ }^{68} \mathrm{Ga}\right.$-NOTGA-AEBSA 3 ) had a TBR that significantly differed from that of the controlse controls (where test animals were first treated with acetazolamide as a CA IX-blocking sulfonamide). ${ }^{27}$

${ }^{68} \mathrm{Ga}\left(t_{1 / 2}=68 \mathrm{~min}\right)$ has been used to label small molecules, biological macromolecules, and nano- and microparticles. ${ }^{33}$ It is a favorable positron emitter because its $\gamma$ emission is negligible and it can be produced in a ${ }^{68} \mathrm{Ge} /{ }^{68} \mathrm{Ga}$ generator, so an on-site cyclotron is not required. ${ }^{34}$ As the parent radionuclide ${ }^{68} \mathrm{Ge}$ has a long half-life $\left(t_{1 / 2}=270.8\right.$ days $)$, it can be stored for relatively long periods. ${ }^{34}$ To make PET imaging with sulfonamides suitable for eventual use in cancer patients, the purpose of the present work is to design and synthesize novel small-molecule ${ }^{68} \mathrm{Ga}$-labeled imaging agents that can selectively target CA IXpositive tumor cells in vivo. Specifically, agents with improved PK properties, CA IX targeting, TBR, and image contrast compared with those previously described are sought.

\section{RESULTS AND DISCUSSION}

Compound Design and Synthesis. Most small-molecule CA inhibitors incorporate a primary sulfonamide functional group, which imparts molecular recognition specificity for the zinc in the active site of CAs but not the metals of other metalloenzymes. $^{29}$ The active site of CA IX is, however, structurally similar to those of CA I and CA II, the major CA isozymes within red blood cells, (CA I: $1.6 \pm 2.3 \mathrm{mg} / \mathrm{g}$ of hemoglobin $(\mathrm{Hb})$; CA II: $1.8 \pm 0.3 \mathrm{mg} / \mathrm{g}$ of $\mathrm{Hb}){ }^{35}$ As a consequence of the binding of sulfonamide-based imaging agents to CA I and CA II in red blood cells, increased background signal and reduced image contrast have hampered the efforts of others in this field. ${ }^{2,36,37}$ Our group has contributed substantially to the development of CA inhibitors with enhanced selectivity for CA IX over CA I and CA II in vitro and, via extrapolation, in vivo. ${ }^{4}$ We have shown that the different CA active sites have variable tolerance to the nature of moieties appended to the aromatic sulfonamide CA targeting group. ${ }^{38-42}$ This attribute allows fine-tuning of the bioactive, physicochemical, and toxicological properties of the compound to better target a particular CA isozyme. ${ }^{43}$ The CA IX targeting agents of this study, compounds 1 ( ${ }^{\text {nat }} \mathrm{Ga}$ and ${ }^{67} \mathrm{Ga}$ ) and 2 ( ${ }^{\text {nat }} \mathrm{Ga},{ }^{67} \mathrm{Ga}$, and ${ }^{68} \mathrm{Ga}$ ), extend our established design principles. These compounds are primary sulfonamides tethered to a metal chelator, 1,4,7,10-tetraazacyclododecane1,4,7,10-tetraacetic acid (DOTA), via either an intervening aliphatic triazole linker (1) or a hydrophilic triazole poly(ethylene glycol) (PEG) linker (2) (Figure 2). The DOTA macrocycle is the workhorse metal ion chelator for molecular imaging agents, forming stable complexes with the PET 
Scheme 2. Synthesis of ${ }^{\text {nat }} \mathrm{Ga}-2^{a}$

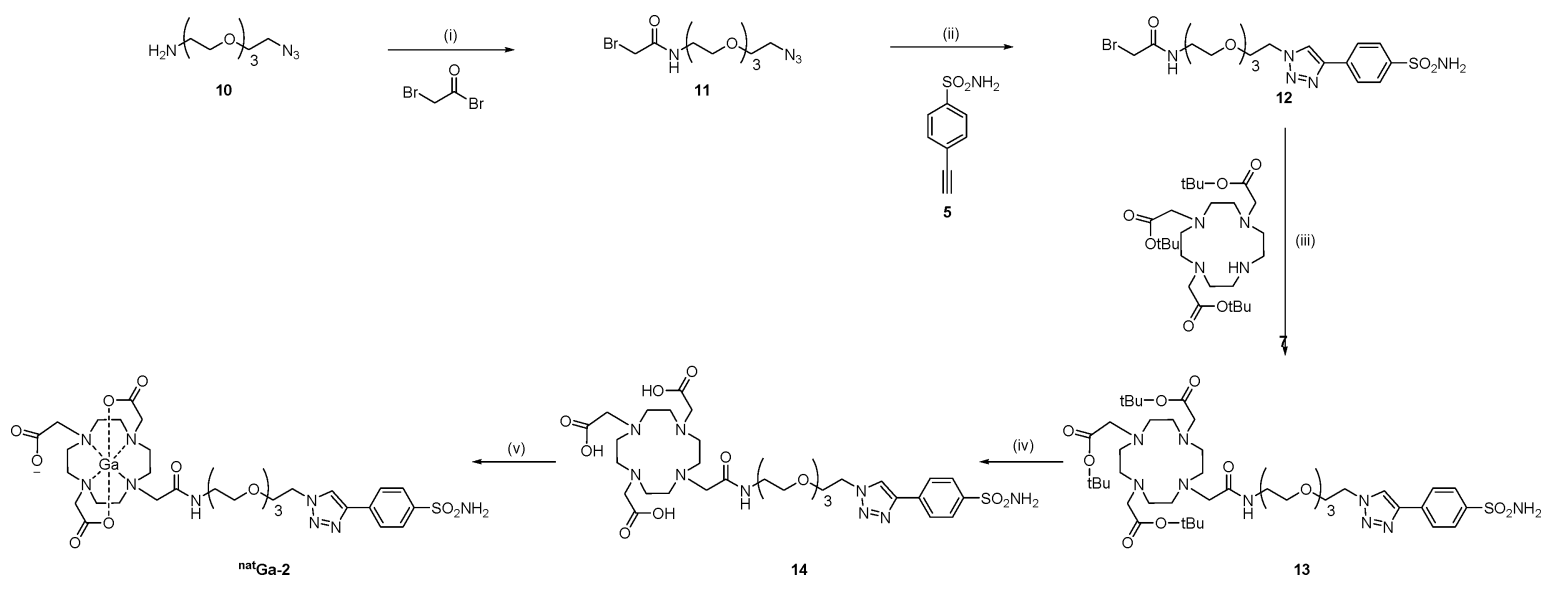

${ }^{a}$ Reagents and conditions: (i) bromoacetyl bromide (3.3 equiv), $\mathrm{NaOH}$ (1.0 M, 2 equiv), DCM, rt, $18 \mathrm{~h}$; (ii) 5 (1.0 equiv), CuSO ${ }_{4}$ (0.01 equiv), sodium ascorbate (0.1 equiv), TBTA (0.01 equiv), $2: 1 \mathrm{DMSO} / \mathrm{H}_{2} \mathrm{O}, 30^{\circ} \mathrm{C}, 18 \mathrm{~h}$; (iii) 7 (1.2 equiv), $\mathrm{K}_{2} \mathrm{CO}_{3}$ ( 1.3 equiv), anhydrous MeCN, $60{ }^{\circ} \mathrm{C}, 3$ h; (iv) 1:1 TFA/DCM, rt, $18 \mathrm{~h}$; (v) $\mathrm{Ga}\left(\mathrm{NO}_{3}\right)_{3} \cdot x \mathrm{H}_{2} \mathrm{O}$ (1.1 equiv), $\mathrm{H}_{2} \mathrm{O}, 80^{\circ} \mathrm{C}, 2-4 \mathrm{~h}$.

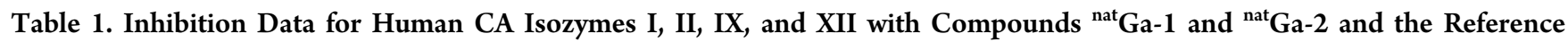
Compound Acetazolamide

\begin{tabular}{|c|c|c|c|c|c|c|c|}
\hline \multirow[b]{2}{*}{ compd } & \multicolumn{4}{|c|}{$K_{\mathrm{i}}(\mathrm{nM})^{a, b}$} & \multicolumn{3}{|c|}{ selectivity $^{c}$} \\
\hline & hCA I & hCA II & hCA IX & hCA XII & CA I/CA IX & CA II/CA IX & CA XII/CA IX \\
\hline acetazolamide $^{d}$ & 250 & 12 & 25 & $\mathrm{n} / \mathrm{a}$ & 10 & 0.48 & $\mathrm{n} / \mathrm{a}$ \\
\hline${ }^{\text {nat }} \mathrm{Ga}-1$ & 387 & 72.5 & 84.7 & 59.6 & 4.57 & 0.85 & 0.70 \\
\hline${ }^{\text {nat }} \mathrm{Ga}-2$ & 169 & 78.3 & 63.1 & 56.8 & 2.67 & 1.24 & 0.90 \\
\hline
\end{tabular}

${ }^{a}$ Errors were in the range of $\pm 5 \%$ of the reported value, from three determinations. ${ }^{b}$ Measured using a stopped-flow assay that monitors the physiological reaction (CA-catalyzed hydration of $\left.\mathrm{CO}_{2}\right) \cdot{ }^{57,58}$ Selectivity is determined by the ratio of $K_{\mathrm{i}}$ values for CA isozymes I, II, and XII relative to CA IX. ${ }^{d}$ Literature acetazolamide values. ${ }^{59}$

imaging isotope ${ }^{68} \mathrm{Ga} .{ }^{44}{ }^{68} \mathrm{Ga}$ is becoming a relevant isotope for routine clinical examinations, with ${ }^{68} \mathrm{Ga}$ PET imaging agents such as ${ }^{68} \mathrm{Ga}$-DOTATATE and ${ }^{68} \mathrm{Ga}$-HBED-PSMA in clinical use. ${ }^{45,46}{ }^{67} \mathrm{Ga}$ is a common radionuclide for use with singlephoton-emission computed tomography (SPECT). The most widely used application is of ${ }^{67} \mathrm{Ga}$-citrate for inflammation and infection imaging. The relatively long half-life $\left(t_{1 / 2}=3.26\right.$ days $)$ makes ${ }^{67} \mathrm{Ga}$ a useful tool for the assessment of key parameters of gallium-based radiopharmaceuticals, including radiochemical stability, metabolic stability, and plasma protein binding, and this in turn informs subsequent decisions on in vivo protocols. The preparation of ${ }^{67} \mathrm{Ga}$ complexes also permits the optimization of radiolabeling conditions, purification methodology, and reformulation procedures prior to using the shorterhalf-life PET radionuclide ${ }^{68} \mathrm{Ga}$. We first synthesized the "cold" compounds, ${ }^{\text {nat }} \mathrm{Ga}-1$ and ${ }^{\text {nat }} \mathrm{Ga}-2$, followed by the corresponding radiolabeled compounds $\left[{ }^{67} \mathrm{Ga}\right]-1$ and $\left[{ }^{67} \mathrm{Ga}\right]-2$ to establish optimized radiolabeling conditions. $\left[{ }^{68} \mathrm{Ga}\right]-2$ was selected as the target compound for in vivo PET imaging studies.

The compound design as [sulfonamide]-[variable linker][DOTA $]$ is deliberately modular. This enables a straightforward synthesis using copper-catalyzed azide-alkyne cycloaddition (CuAAC), or "click chemistry", to combine the components. $\mathrm{CuAAC}$ is one of the most accomplished reactions for combining groups to pool their individual properties into a single molecule. ${ }^{47}$ The biopharmaceutical stability of the resulting triazole is favorable, as it is resistant to acidic, basic, reductive, and oxidative conditions in addition to enzymatic degradation. ${ }^{48}$ Scaffold 2 employs a tetraethylene glycol linker, which is a shortened PEG chain with good biopharmaceutical properties, polarity, and water solubility, aiding the eventual formulation. ${ }^{49}$ The PEG-based linker was additionally selected to enhance the likelihood that the agents would have improved specificity for CA IX. The increased polarity reduces plasma protein binding and membrane permeability and thus may lessen the off-target binding to CA I and CA II in red blood cells. ${ }^{50}$ A previous generation of DOTA-based scaffolds were designed by Rami and co-workers, but to the best of our knowledge, these were not radiolabeled or evaluated as CA IX imaging agents in vivo. ${ }^{51,52}$

The target compounds $\mathbf{1}$ and $\mathbf{2}$ are synthesized from three modular components, [sulfonamide], [linker], and [DOTA], with incorporation of the gallium cation as the final step (Schemes 1 and 2). The synthesis of the [sulfonamide] component, 4-ethynylbenzenesulfonamide (5), has been described previously. ${ }^{53}$ The [linker] components, 4 and 11, were designed with orthogonal end groups. An azide facilitates the reaction with 5 via $\mathrm{CuAAC}$, while the bromide provides an orthogonal leaving group facilitating the $\mathrm{S}_{\mathrm{N}} 2$ substitution reaction with the [DOTA] component 7 . Linkers 4 and 11 were prepared by reaction of bromoacetyl bromide (3.3 equiv) with amino azides $3^{54}$ and 10, respectively. ${ }^{55}$ The [sulfonamide] component 5 and [linker] components $\mathbf{4}$ and $\mathbf{1 1}$ were subjected to $\mathrm{CuSO}_{4}(0.01-0.05$ equiv), sodium ascorbate $(0.1$ equiv), and TBTA (0.01-0.05 equiv) to generate 6 and 12, respectively. The removal of excess copper ions from 6 and 12 was achieved by a solid EDTA chase or by washing the organic phases with EDTA $(1.0 \mathrm{M})$ in ammonium hydroxide (28.0$30.0 \%, \mathrm{NH}_{3}$ basis) solution. The [DOTA] component 7 was prepared from commercially available cyclen as described by 
Prashun et al. ${ }^{56} S_{N} 2$ substitution of 6 and 12 with 7 using anhydrous conditions gave the $t \mathrm{Bu}$-protected compounds $\mathbf{8}$ and 13 in reasonable yields. Treatment of compounds 8 and 13 with either neat formic acid or 1:1 TFA/DCM removed the $t \mathrm{Bu}$ protecting groups to provide the nonmetalated precursor compounds 9 and 14 in high yield. Next, the target ${ }^{\text {nat }} \mathrm{Ga}$ complexes, ${ }^{\text {nat }} \mathrm{Ga}-1$ and ${ }^{\text {nat }} \mathrm{Ga}-2$, were prepared in quantitative yield from 9 and 14 using $\mathrm{Ga}\left(\mathrm{NO}_{3}\right)_{3} \cdot x \mathrm{H}_{2} \mathrm{O}$ in $\mathrm{H}_{2} \mathrm{O}$ with the $\mathrm{pH}$ adjusted to $\mathrm{pH} 4.5$ with $1.0 \mathrm{M} \mathrm{HCl}$ or $1.0 \mathrm{M} \mathrm{KOH}$. Compounds 9 and 14 were purified by reversed-phase HPLC (RP-HPLC) prior to biological evaluation and radiolabeling with ${ }^{67} \mathrm{Ga}$ and $/$ or ${ }^{68} \mathrm{Ga}$.

Carbonic Anhydrase Binding. The CA binding data for ${ }^{\text {nat }} \mathrm{Ga}-1$, ${ }^{\text {nat }} \mathrm{Ga}-2$, and the reference CA inhibitor acetazolamide were measured for the cancer-associated CA isozymes CA IX and XII and the off-target CA isozymes CA I and II. Compounds ${ }^{\text {nat }} \mathrm{Ga}-1$ and ${ }^{\text {nat }} \mathrm{Ga}-2$ have low affinity for CA I but bind equally well to CA II, CA IX, and CA XII $\left(K_{\mathrm{i}}\right.$ range 59.6-84.7 $\mathrm{nM}$ ) (Table 1). Binding to CA II supports the significance and importance of designing probes to have reduced cell-membrane permeability, as this limits access of the probes to the intracellular CA II.

Radiochemistry. Compounds 9 and $\mathbf{1 4}$ were successfully radiolabeled with ${ }^{67} \mathrm{Ga}$ under standard conditions (0.1 M sodium acetate, $\mathrm{pH} 4.5,10 \mathrm{~min}, 95^{\circ} \mathrm{C}$ ). To test the robustness of the radiolabeling method developed, the compound amount was progressively reduced from 10 to $1 \mathrm{nmol}$ and the radiochemical yield quantified by RP-HPLC (Table 2). It was

Table 2. Radiochemical Yields of $\left[{ }^{67} \mathrm{Ga}\right]-1$ and $\left[{ }^{67} \mathrm{Ga}\right]-2$ at Varying Compound Concentrations ${ }^{a}$

\begin{tabular}{ccc} 
& \multicolumn{2}{c}{ radiochemical yield $(\%)^{b}$} \\
\cline { 2 - 3 } amount of compd (nmol) & $\mathbf{9} \rightarrow\left[{ }^{67} \mathrm{Ga}\right]-\mathbf{1}$ & $\mathbf{1 4} \rightarrow\left[{ }^{67} \mathrm{Ga}\right]-\mathbf{2}$ \\
25 & $100^{c}$ & 100 \\
10 & $98 \pm 1.4^{d}$ & $98.5 \pm 0.7^{d}$ \\
5 & $\mathrm{n} / \mathrm{a}$ & $>99$ \\
2 & 98 & 100 \\
1 & 61 & $>99$
\end{tabular}

${ }^{a}$ Reaction conditions: Compound 9 or $\mathbf{1 4}(1 \mathrm{mM}$ in water), sodium acetate $(0.1 \mathrm{M}$, to $\mathrm{pH} 4.5),{ }^{67} \mathrm{GaCl}_{3}(18-21 \mathrm{MBq}$ in $0.1 \mathrm{M} \mathrm{HCl}), 95$ ${ }^{\circ} \mathrm{C}, 10$ min. ${ }^{b}$ As determined by RP-HPLC (conditions available in the Supporting Information). ${ }^{c}$ Labeling in HEPES buffer proceeded with $>99 \%$ radiochemical yield. ${ }^{d} \pm$ standard deviation based on two radiolabeling experiments.

shown that 9 was successfully radiolabeled (to give $\left[{ }^{67} \mathrm{Ga}\right]-\mathbf{1}$ ) down to $2 \mathrm{nmol}$ of compound (98\%) but at $1 \mathrm{nmol}$, only $61 \%$ radiolabeling was achieved. However, 14 was radiolabeled efficiently (to give $\left[{ }^{67} \mathrm{Ga}\right]-2$ ) down to $1 \mathrm{nmol}$ of compound (>99\%). Purification of the radiolabeled products was carried out using either RP-HPLC or rapid reversed phase C-18 solidphase extraction (SPE). Both $\left[{ }^{67} \mathrm{Ga}\right]-1$ and $\left[{ }^{67} \mathrm{Ga}\right]-2$ were reformulated into phosphate-buffered saline (PBS).

Compound 14 was radiolabeled with ${ }^{68} \mathrm{Ga}(200-800 \mathrm{MBq}$, eluted from a ${ }^{68} \mathrm{Ge} /{ }^{68} \mathrm{Ga}$ generator (IDB Holland, BaarleNassau, The Netherlands) in about $1 \mathrm{~mL}$ of $0.6 \mathrm{M} \mathrm{HCl}$ ), in 400 $\mu \mathrm{L}$ of $3.0 \mathrm{M}$ sodium acetate or ammonium acetate $(\mathrm{pH} 4.3,10$ min, $\left.99{ }^{\circ} \mathrm{C}\right)$ in high radiochemical purity $(>95 \%)$ as determined by radio-RP-HPLC (Inertsil ODS C18, $5 \mu \mathrm{M}, 4.6$ $\mathrm{mm} \times 250 \mathrm{~mm}, 100: 0 \rightarrow 0: 100 \mathrm{H}_{2} \mathrm{O}+0.1 \%$ TFA/MeCN + $0.1 \% \mathrm{TFA}, 1.0 \mathrm{~mL} / \mathrm{min}$ ).
Biopharmaceutical Properties. The stability of the ${ }^{67} \mathrm{Ga}-$ radiolabeled compounds $\left[{ }^{67} \mathrm{Ga}\right]-1$ and $\left[{ }^{67} \mathrm{Ga}\right]-2$ was examined in PBS ( $\mathrm{pH}$ 7.4). The compounds were found to be stable, with $\geq 95 \%$ of the parent compounds remaining after $18 \mathrm{~h}$ of incubation at $37.5{ }^{\circ} \mathrm{C}$ and $\geq 90 \%$ after $96 \mathrm{~h}$ of incubation. The protein binding of $\left[{ }^{67} \mathrm{Ga}\right]-1$ and $\left[{ }^{67} \mathrm{Ga}\right]-2$ to human serum was minimal $(<7 \%, n=3)$ after 48 h. $\left[{ }^{67} \mathrm{Ga}\right]-2$ exhibited favorable radiochemical purity (data not shown), good stability, and good preliminary physicochemical properties. Hence, additional biopharmaceutical properties of cold ${ }^{\text {nat }} \mathrm{Ga}-2$ were assessed (Table 3); by extrapolation, these properties should reflect

Table 3. Biopharmaceutical Properties of Compound ${ }^{\text {nat }} \mathrm{Ga}-2$

\begin{tabular}{|c|c|c|c|c|}
\hline $\begin{array}{l}\text { degradation } \\
t_{1 / 2}(\min )^{a}\end{array}$ & $\begin{array}{l}\text { in vitro } \mathrm{CL}_{\text {int }}(\mu \mathrm{L} \\
\min ^{-1}(\mathrm{mg} \text { of } \\
\left.\text { protein })^{-1}\right)^{a}\end{array}$ & $\begin{array}{c}\text { microsome- } \\
\text { predicted } \\
E_{\mathrm{H}}^{b}\end{array}$ & $\begin{array}{c}\left.P_{\text {app }}\right)^{c} \\
(\mathrm{~cm} / \mathrm{s})^{c}\end{array}$ & $\begin{array}{l}\text { plasma } \\
\text { protein } \\
\text { binding } \\
(4 \mathrm{~h})^{d}\end{array}$ \\
\hline$>247$ & $<7$ & $<0.13$ & $<0.7$ & $39 \%$ \\
\hline
\end{tabular}

${ }^{a}$ The metabolic stability parameters for compound ${ }^{\text {nat }} \mathrm{Ga}-2$ are based on NADPH-dependent degradation profiles in mouse liver microsomes. In vitro $\mathrm{CL}_{\text {int }}$ is the intrinsic clearance value. ${ }^{b}$ Predicted in vivo hepatic extraction ratio $\left(E_{\mathrm{H}}\right) \cdot{ }^{c} P_{\text {app }}=$ apparent permeability across Caco-2 monolayers. ${ }^{d}$ Average of duplicate determinations.

those expected for the radiolabeled analogue $\left[{ }^{68} \mathrm{Ga}\right]-2$. The in vitro metabolic stability of compound ${ }^{\text {nat }} \mathrm{Ga}-2$ in mouse liver microsomes was measured in the presence and absence of $\mathrm{NADPH}$, the cofactor required for oxidative metabolism by cytochrome P450s. Compound ${ }^{\text {nat }} \mathrm{Ga}-2$ exhibited minimal microsomal degradation $\left(t_{1 / 2}>247 \mathrm{~min}\right)$, and it is expected that compound ${ }^{\text {nat }} \mathrm{Ga}-2$ is subject to low hepatic clearance in vivo. The in vitro intrinsic clearance of ${ }^{\text {nat }} \mathrm{Ga}-2$ was low $(<7 \mu \mathrm{L}$ $\left.\min ^{-1}(\mathrm{mg} \text { of protein })^{-1}\right)$. The in vitro membrane permeability $\left(P_{\text {app }}\right)$ of ${ }^{\text {nat }} \mathrm{Ga}-2$ in the Caco-2 cell model ( $\left.\mathrm{pH} 7.4\right)$ was measured. ${ }^{\text {nat }} \mathrm{Ga}-2$ was not detected in the Caco-2 assay acceptor chamber, while good mass balance (92\% $\pm 6 \%$ ) confirmed minimal retention of the compound within the cell monolayer and minimal nonspecific adsorption. The experimental value measured, $P_{\text {app }}<0.7 \mathrm{~cm} / \mathrm{s}$, indicates that ${ }^{\text {nat }} \mathrm{Ga}-2$ has very low cell membrane permeability. The stability and extent of plasma protein binding of ${ }^{\text {nat }} \mathrm{Ga}-2$ in mouse plasma was analyzed. The measured concentration of ${ }^{\text {nat }} \mathrm{Ga}-2$ in mouse plasma samples $\left(37^{\circ} \mathrm{C}\right)$ quenched at 2 min was unchanged. However, at 10 min the concentration of ${ }^{\text {nat }} \mathrm{Ga}-2$ had dropped but then remained steady over the remainder of the $4 \mathrm{~h}$ incubation. Plasma protein binding of ${ }^{\text {nat }} \mathrm{Ga}-2$ was low (39\%) following $4 \mathrm{~h}$ of incubation. The cytotoxicity and cell viability of ${ }^{\text {nat }} \mathrm{Ga}-2$ were tested via a standard methyl thiazolyl tetrazolium assay, with no toxicity observed up to $1 \mathrm{mM}{ }^{\text {nat }} \mathrm{Ga}-2$ in normoxia (data not shown). Collectively, these additional properties of ${ }^{\text {nat }} \mathrm{Ga}-2$ are indicative of a safe, well-tolerated compound with physicochemical properties suited to preferential targeting of CA IX over intracellular CAs and hence a favorable TBR of the corresponding ${ }^{68} \mathrm{Ga}$ compound.

Small-Animal PET and PET/CT Imaging Studies. Our lead compound, $\left[{ }^{68} \mathrm{Ga}\right]-2$, was chosen for follow-up in vivo PET studies and was injected intravenously into mice bearing HCT116 tumors with high or low CA IX expression to assess the selectivity of uptake using PET. The efficiency of CA IX genetic silencing was determined by Western blot analysis and immunofluorescence. In agreement with previous studies, ${ }^{60,61}$ CA IX levels were significantly lower in CA IX-knockdown tumors than in CA IX-expressing tumors (Figure 3A,B). 
A

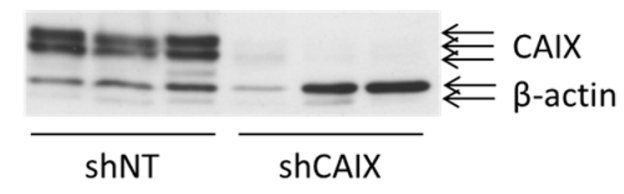

C ShNT

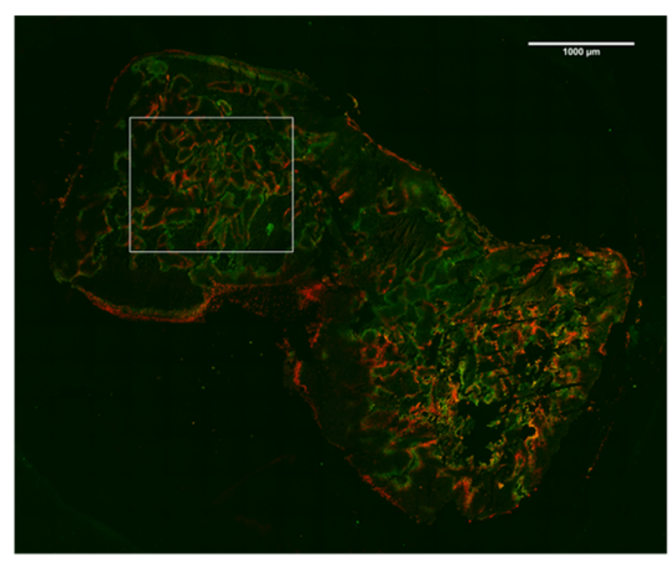

ShCAIX
B
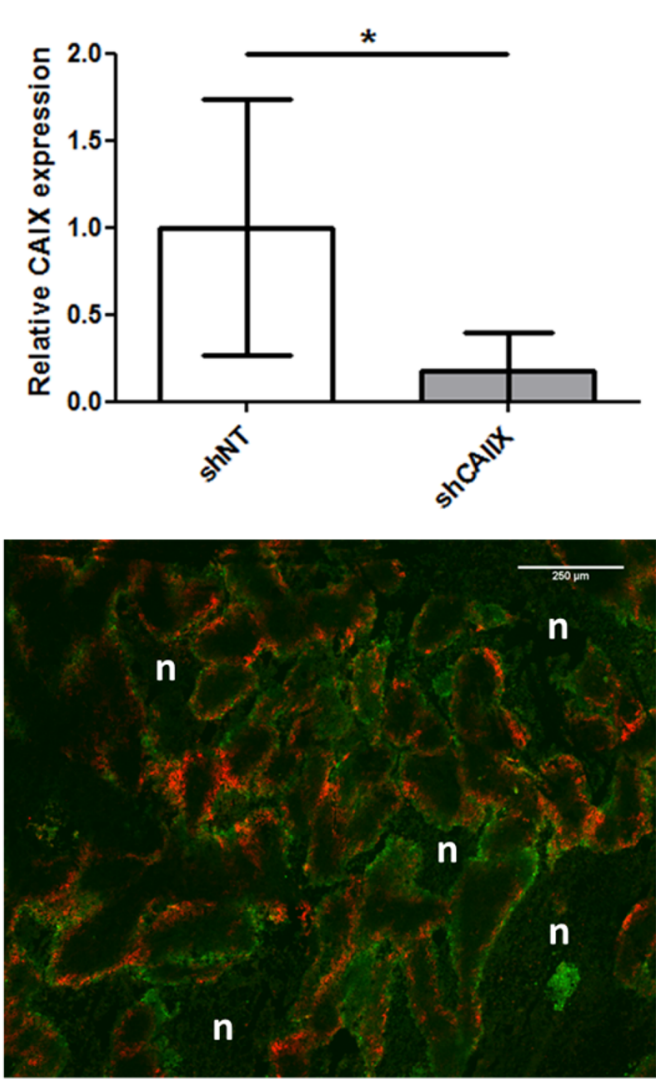
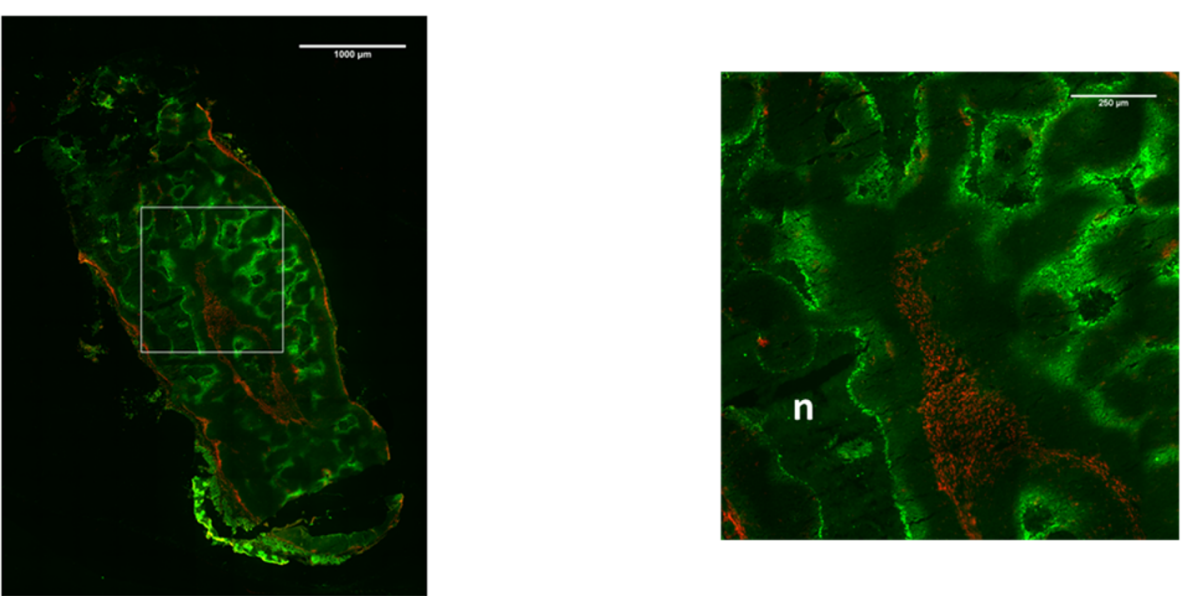

Figure 3. CA IX expression in mice bearing CA IX-expressing (shNT) or CA IX-knockdown (shCA IX) tumors. (A) Western blot showing CA IX protein levels in representative samples. (B) Quantification of CA IX protein levels as determined by Western blot for all shNT and shCA IX tumors. (C) Immunofluorescence staining of CA IX (red) and the hypoxia marker pimonidazole (green). Right-side images are magnifications of areas within the white rectangles in the left-side images. "n" indicates necrotic areas.

Additionally, as determined by immunofluorescence staining, membranous CA IX expression was colocalized with the exogenous hypoxia marker pimonidazole in CA IX-expressing tumors, whereas in CA IX-knockdown tumors very low or no CA IX expression was present (Figure 3C). This confirms efficient CA IX knockdown and thus CA IX-dependent uptake of $\left[{ }^{68} \mathrm{Ga}\right]-2$.

In order to determine the optimal imaging time point, $\mu \mathrm{PET}$ scans were acquired hourly from 1 to $4 \mathrm{~h}$ post injection (h p.i.) of $\left[{ }^{68} \mathrm{Ga}\right]-2$. Tumor uptake in the CA IX-expressing model was clearly observed and found to be highest at $1 \mathrm{~h}$ p.i. (Figure 4A). This time point was selected for all of the subsequent experiments. Additionally, it was found that the agent was rapidly excreted renally, as observed by the high presence of the agent in the kidneys and bladder. Mass spectrometry analysis of the urine confirmed that the compound was cleared without metabolism.

To assess the compound selectivity, uptake was compared between mice with either CA IX-expressing or CA IXknockdown tumors. Although CA IX-knockdown tumors tend to grow slower than their CA IX-expressing counterparts, ${ }^{61}$ the tumor volumes at the time of scans were not statistically different $(P=0.422)$ between the two groups (315 \pm 104 and $277 \pm 63 \mathrm{~mm}^{3}$ for CA IX-expressing and CA IX- 


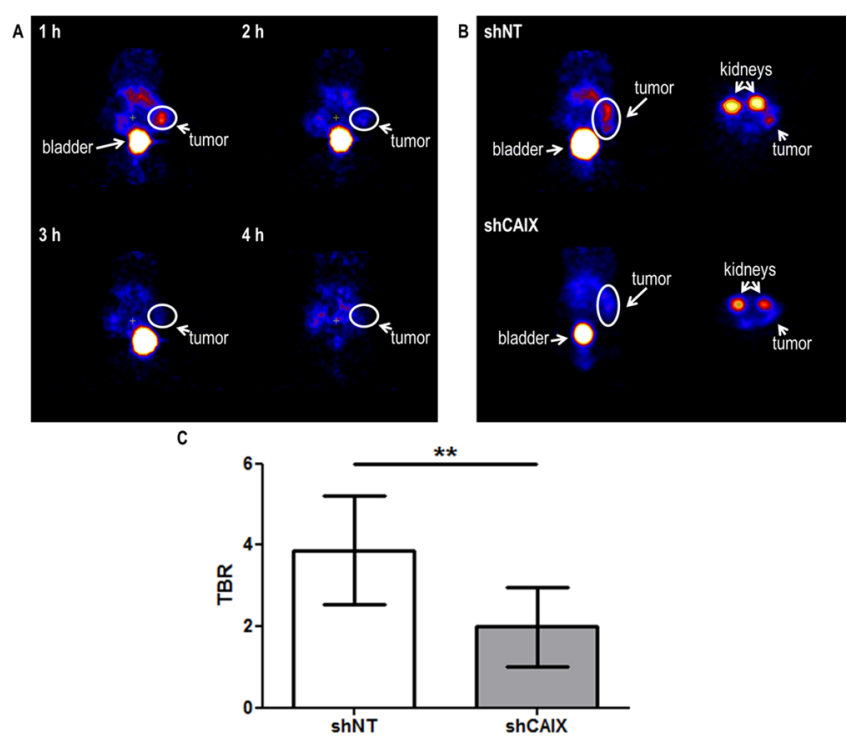

Figure 4. $\left[{ }^{68} \mathrm{Ga}\right]-2$ uptake in mice bearing CA IX-expressing (shNT) or CA IX-knockdown (shCA IX) tumors. (A) Representative $\mu$ PET scans at 1-4 h p.i. in a shNT-tumor bearing mouse. (B) Representative $\mu$ PET scans at $1 \mathrm{~h}$ p.i. (C) TBRs of $\left[{ }^{68} \mathrm{Ga}\right]-2$ uptake determined from PET scans of shNT-tumor bearing mice $(n=11)$ and shCA IX-tumor bearing mice $(n=6)$. $* *, P<0.01$.

knockdown tumors, respectively). The TBR was significantly higher $(P<0.01)$ in mice bearing CA IX-expressing tumors $(3.87 \pm 1.34)$ compared with mice bearing CA IX-knockdown tumors $(1.99 \pm 0.99)$ (Figure $4 \mathrm{~B}, \mathrm{C})$. Uptake of $\left[{ }^{68} \mathrm{Ga}\right]-2$ was therefore found to be CA IX-dependent. However, the lack of anatomical information in the acquired PET images prompted us to verify colocalization with computed tomography (CT). Therefore, the experiments were repeated to include CT scans, enabling better tumor delineation in the fused PET/CT images and more clearly confirming the localization of the agent in the tumor. Again the tumor volumes at the time of scans were not statistically different $(P=0.071)$ between the two groups (492 \pm 390 and $125 \pm 44 \mathrm{~mm}^{3}$ for CA IX-expressing and CA IXknockdown tumors, respectively). Similar to the first experi- ment, the TBR was significantly higher $(P<0.01)$ in mice bearing CA IX-expressing tumors $(2.36 \pm 0.424)$ than in mice bearing CA IX-knockdown tumors $(1.30 \pm 0.350)$ (Figure $5 \mathrm{~A}, \mathrm{~B})$. Autoradiography analysis of tumor sections supported the $\mu$ PET results, showing a higher signal intensity relative to injected dose (ID) in CA IX-expressing tumors $\left(9.12 \times 10^{-7} \pm\right.$ $\left.7.25 \times 10^{-7}\right)$ compared with CA IX-knockdown tumors $(3.84$ $\times 10^{-7} \pm 1.53 \times 10^{-7}$ ) (Figure $5 \mathrm{C}$ ). Low uptake of $\left[{ }^{68} \mathrm{Ga}\right]-2$ was also observed in the CA IX-knockdown model, which can be explained by residual CA IX expression in these tumors. Nevertheless, the significantly higher uptake of $\left[{ }^{68} \mathrm{Ga}\right]-2$ in tumors with high CA IX expression confirms the selectivity of this imaging compound.

\section{CONCLUSION}

This study provides the first evidence of noninvasive, specific detection of CA IX in vivo using a CA IX-targeting smallmolecule PET radiotracer, $\left[{ }^{68} \mathrm{Ga}\right]-2$. The synthesis of the unlabeled precursor of $\left[{ }^{68} \mathrm{Ga}\right]-2$ (compound 14) and the radiochemistry to introduce ${ }^{68} \mathrm{Ga}$ were straightforward, proceeded in good yields, and were reproducible, and the biopharmaceutical properties were favorable. This study is a promising step toward a new predictive tool that will enable testing of the potential of CA IX expression as a biomarker for selection of patients eligible for CA IX-targeting anticancer therapies.

\section{EXPERIMENTAL SECTION}

Chemistry-General Methods. All of the starting materials and reagents were purchased from commercial suppliers. Where specified, solvents were available commercially dried or were dried prior to use. Reactions took place open to the atmosphere unless otherwise specified. Reaction progress was monitored by thin-layer chromatography (TLC) using silica gel 60 F254 plates with detection by shortwave UV fluorescence $(\lambda=254 \mathrm{~nm})$ and staining with ninhydrin $(1 \mathrm{~g}$ of ninhydrin, $200 \mathrm{~mL}$ of EtOH, $8 \mathrm{~mL}$ of acetic acid), $\mathrm{KMnO}_{4}(0.75 \mathrm{~g}$ of $\mathrm{KMnO}_{4}, 5 \mathrm{~g}$ of $\mathrm{K}_{2} \mathrm{CO}_{3}, 75 \mathrm{mg}$ of $\mathrm{NaOH}, 100 \mathrm{~mL}$ of $\mathrm{H}_{2} \mathrm{O}$ ), or vanillin stain $\left(5 \mathrm{~g}\right.$ of vanillin in an 87:10.2:2.8 EtOH/ $\mathrm{H}_{2} \mathrm{O} / \mathrm{H}_{2} \mathrm{SO}_{4}$ mixture with subsequent heating); by TLC using RP-18 silica gel 60 F254 plates with detection by short-wave UV fluorescence; or by highperformance liquid chromatography (HPLC) on an Agilent 1100
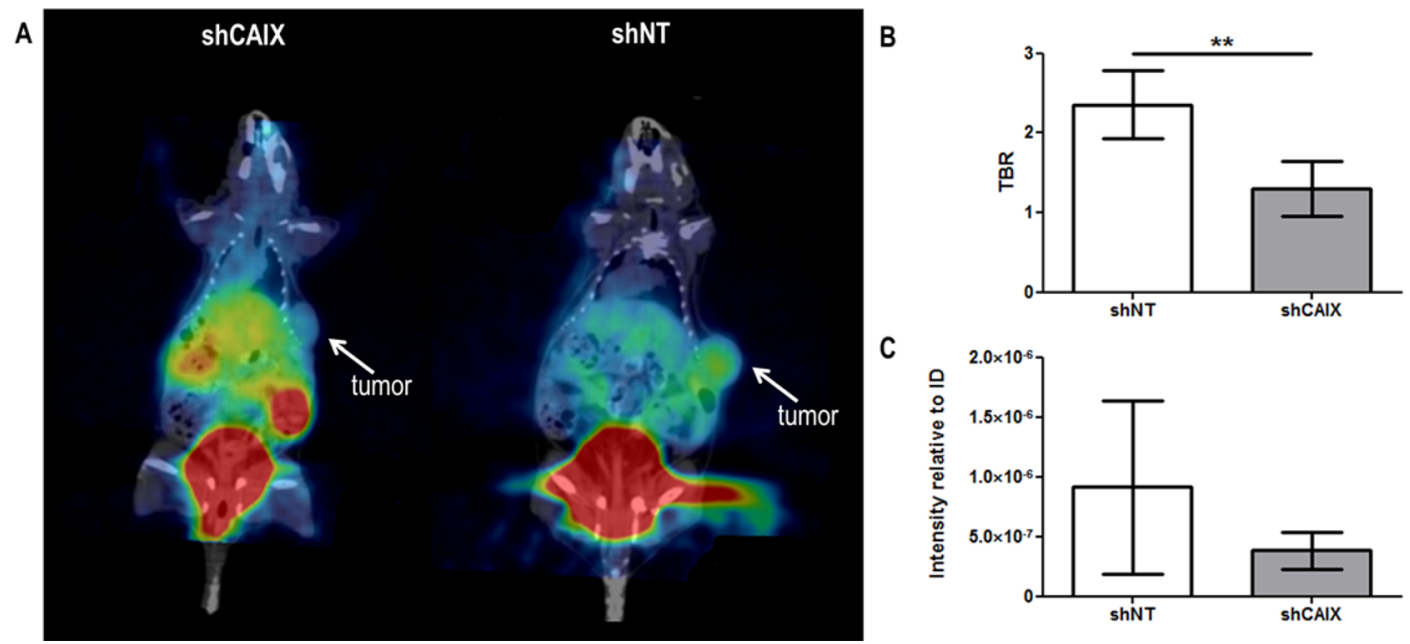

Figure 5. $\left[{ }^{68} \mathrm{Ga}\right]-2$ uptake in mice bearing CA IX-expressing (shNT) or CA IX-knockdown (shCA IX) tumors. (A) Representative $\mu$ PET/CT fusion images at $1 \mathrm{~h}$ p.i. (B) TBRs of $\left[{ }^{68} \mathrm{Ga}\right]-2$ uptake determined from PET scans of shNT-tumor bearing mice $(n=4)$ and shCA IX-tumor bearing mice $(n=5)$. **, $P<0.01$. (C) Signal intensity relative to injected dose (ID) as determined by autoradiography analysis of tumor sections from shNTtumor bearing mice $(n=6)$ and shCA IX-tumor bearing mice $(n=6)$. 


\section{Scheme 3. Atom Labeling of DOTA Compounds}
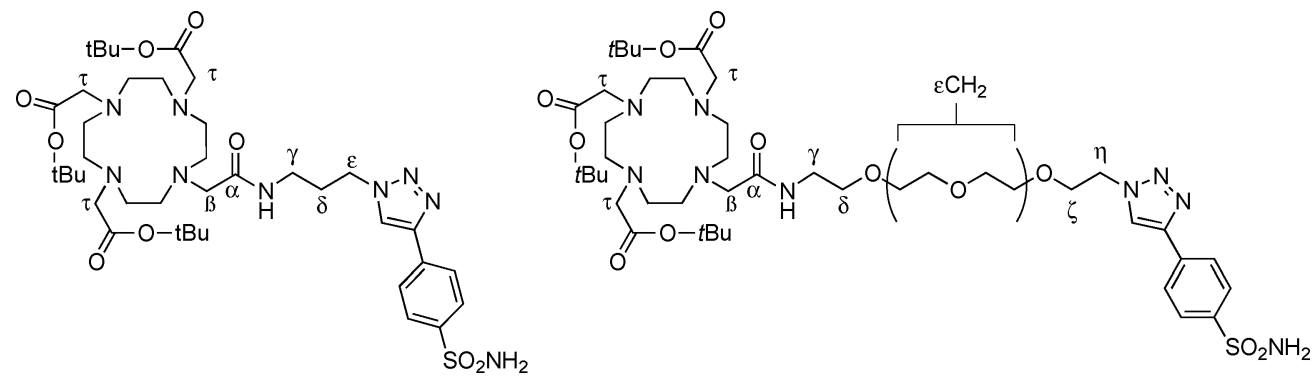

system using a Thermo Betasil C18 column $(150 \mathrm{~mm} \times 4.6 \mathrm{~mm}, 5$ $\mu \mathrm{m})$ and a gradient method of 95:5 $\rightarrow 5: 95 \mathrm{H}_{2} \mathrm{O}(+0.1 \%$ TFA)/ acetonitrile $(+0.1 \% \mathrm{TFA})$ over $10 \mathrm{~min}$ at a flow rate of $1 \mathrm{~mL} / \mathrm{min}$. Silica gel flash chromatography was performed using silica gel $60 \AA$ (230-400 mesh). NMR $\left({ }^{1} \mathrm{H},{ }^{13} \mathrm{C}\left\{{ }^{1} \mathrm{H}\right\},{ }^{1} \mathrm{H}-{ }^{1} \mathrm{H}\right.$ gCOSY, and HSQC) spectra were recorded on either a 400 or $500 \mathrm{MHz}$ spectrometer at 30 ${ }^{\circ} \mathrm{C}$. ${ }^{1} \mathrm{H}$ NMR spectra were referenced to the residual solvent peak $\left(\mathrm{CDCl}_{3}, 7.26 \mathrm{ppm}\right.$; DMSO- $\left.d_{6}, 2.50 \mathrm{ppm}\right) .{ }^{13} \mathrm{C}$ NMR spectra were referenced to the internal solvent $\left(\mathrm{CDCl}_{3}, 77.0 \mathrm{ppm}\right.$; DMSO- $d_{6}, 39.5$ $\mathrm{ppm})$. Multiplicity is indicated as follows: $\mathrm{s}$ (singlet), $\mathrm{d}$ (doublet), $\mathrm{t}$ (triplet), q (quartet), quint (quintuplet), m (multiplet), dd (doublet of doublets), ddd (doublet of doublets of doublets), b (broad). Coupling constants $(J)$ are reported in hertz. Mestrenova 6.1 software was used for NMR analysis. Melting points are uncorrected. Mass spectra (lowand high-resolution) were recorded using electrospray as the ionization technique in positive-ion and/or negative-ion mode as stated. The purities of all final compounds $\left(\mathbf{8}, 9,{ }^{\text {nat }} \mathrm{Ga}-\mathbf{1}\right.$, and $\left.{ }^{\text {nat }} \mathrm{Ga}-2\right)$ were $\geq 95 \%$ as determined by HPLC with UV detection. Compounds 3, 4, 5, 7, and 10 were synthesized as described elsewhere, with characterization in agreement with the literature..$^{53,54,56,62-65}$ The atom labeling of DOTA compounds used for NMR assignments is shown in Scheme 3.

Chemistry-Synthesis Methods. General Procedure 1: Synthesis of Brominated [linker] Components. The amino azide precursor ( 1 equiv) was suspended in a biphasic $\mathrm{DCM} / \mathrm{NaOH}(\mathrm{aq})$ solution $(2: 1,2-3$ equiv of $\mathrm{NaOH})$ and cooled to $0{ }^{\circ} \mathrm{C}$. Bromoacetyl bromide ( 3 equiv) was added dropwise to the DCM layer. The solution was then stirred vigorously overnight at $\mathrm{rt}$. The reaction mixture was diluted with $\mathrm{DCM}$ and $\mathrm{H}_{2} \mathrm{O}$, and the aqueous fraction was extracted with DCM $(2 \times 50 \mathrm{~mL})$. The organic fractions were combined and washed with $50 \mathrm{mM} \mathrm{Na} \mathrm{CO}_{3}(3 \times 50 \mathrm{~mL})$, dried with $\mathrm{MgSO}_{4}$, filtered, and concentrated. The crude compound was sufficiently pure and used crude in the next step.

General Procedure 2: Addition of "Cold" Ga. The parent compound (9 or 14, 1 equiv) was suspended in $\mathrm{H}_{2} \mathrm{O}$, and excess $\mathrm{Ga}\left(\mathrm{NO}_{3}\right)_{3} \cdot x \mathrm{H}_{2} \mathrm{O}(\mathrm{aq})$ was added. The $\mathrm{pH}$ of the reaction mixture was adjusted to $\sim 4.5$ using $\mathrm{KOH}(1.0 \mathrm{M})$ or $\mathrm{HCl}(1.0 \mathrm{M})$. The reaction mixture was heated at $80{ }^{\circ} \mathrm{C}$, and the $\mathrm{pH}$ was monitored and adjusted accordingly to maintain $\mathrm{pH} 4.5$. The reaction mixture stabilized after $\sim 2 \mathrm{~h}$. Reaction progress was monitored by LC-MS. Products were purified by RP-18 flash column chromatography $\left(\mathrm{H}_{2} \mathrm{O} / \mathrm{MeOH}\right.$ 100:0 $\rightarrow$ 5:95), and the solvent was removed in vacuo, leaving a hygroscopic solid.

$\mathrm{N}$-(3-Azidopropyl)-2-bromoacetamide (4). The title compound was synthesized from 3-azido-1-propanamine $\mathrm{HCl}$ salt (3) $(1.5 \mathrm{~g}, 11$ $\mathrm{mmol}$ ) and $\mathrm{NaOH}$ (2 equiv) using general procedure 1 and isolated as a yellow oil $(1.9 \mathrm{~g}, 78 \%) . R_{\mathrm{f}} 0.13(90: 10 \mathrm{DCM} / \mathrm{MeOH}) .{ }^{1} \mathrm{H}$ NMR $\left(500 \mathrm{MHz}, \mathrm{CDCl}_{3}\right): \delta_{\mathrm{H}} 6.72($ br s, $1 \mathrm{H}, \mathrm{NH}), 3.88\left(\mathrm{~s}, 2 \mathrm{H}, \beta \mathrm{CH}_{2}\right)$, $3.40-3.36\left(\mathrm{~m}, 4 \mathrm{H}, \gamma \mathrm{CH}_{2}, \varepsilon \mathrm{CH}_{2}\right.$ ), 1.82 (quint, $2 \mathrm{H}, J=6.60 \mathrm{~Hz}, \delta \mathrm{CH}_{2}$ ). ${ }^{13} \mathrm{C}$ NMR $\left(125 \mathrm{MHz}, \mathrm{CDCl}_{3}\right): \delta_{\mathrm{C}} 165.8(\alpha \mathrm{C}=\mathrm{O}), 49.5\left(\varepsilon \mathrm{CH}_{2}\right.$ or $\left.\gamma \mathrm{CH}_{2}\right), 38.1\left(\varepsilon \mathrm{CH}_{2}\right.$ or $\left.\gamma \mathrm{CH}_{2}\right), 29.3\left(\beta \mathrm{CH}_{2}\right), 28.6\left(\delta \mathrm{CH}_{2}\right)$. LRMS $\left(\mathrm{ESI}^{-}\right): m / z=221,219\left[\mathrm{M}-\mathrm{H}^{81} \mathrm{Br},{ }^{79} \mathrm{Br}\right]^{-}$. HRMS (ESI) ${ }^{+}:$calcd for $\mathrm{C}_{5} \mathrm{H}_{9}{ }^{79} \mathrm{BrN}_{4} \mathrm{NaO}^{+}$, 242.9852; found, 242.9852. The ${ }^{1} \mathrm{H}$ NMR data were in agreement with the data reported in the literature. ${ }^{62}$

2-Bromo-N-(3-[4-(4-sulfamoylphenyl)-1H-1,2,3-triazol-1-yl]propyl)acetamide (6). $\mathrm{CuSO}_{4}(7 \mathrm{mg}, 0.027 \mathrm{mmol})$ and sodium ascorbate $(10.8 \mathrm{mg}, 0.055 \mathrm{mmol})$ were combined in $1 \mathrm{~mL}$ of $\mathrm{H}_{2} \mathrm{O}$ and added to a solution of alkyne $11(100 \mathrm{mg}, 0.55 \mathrm{mmol})$, azide 5 (145 $\mathrm{mg}, 0.66 \mathrm{mmol}$ ), and TBTA (14.5 mg, $0.027 \mathrm{mmol}$ ) in DMSO (2 $\mathrm{mL})$. The mixture was left to stir at $45{ }^{\circ} \mathrm{C}$, and the reaction was monitored by TLC. Once the reaction was complete $(1.5 \mathrm{~h})$, the reaction mixture was filtered through Celite and washed with $\mathrm{H}_{2} \mathrm{O}$, and the filtrate was redissolved in DMF. The DMF was concentrated to a minimum amount before EtOAc $(30 \mathrm{~mL})$ was added and the organic phase was rapidly washed with EDTA in ammonium hydroxide $(1.0 \mathrm{M}, 50 \mathrm{~mL})$. The organic fraction was dried $\left(\mathrm{MgSO}_{4}\right)$ and filtered, and the remaining residue was purified by flash column chromatography (90:10 EtOAc/MeOH). The product was isolated as a white powder $(0.04 \mathrm{~g}, 18 \%) . R_{\mathrm{f}} 0.36(80: 20 \mathrm{DCM} / \mathrm{MeOH}), \mathrm{mp}$ $182-185{ }^{\circ} \mathrm{C} .{ }^{1} \mathrm{H}$ NMR $\left(500 \mathrm{MHz}\right.$, DMSO- $\left.d_{6}\right): \delta_{\mathrm{H}} 8.70(\mathrm{~s}, 1 \mathrm{H}$, triazole $\mathrm{CH}), 8.39(\mathrm{t}, 1 \mathrm{H}, \mathrm{NH}), 8.02(\mathrm{~m}, 2 \mathrm{H}, 2 \times \mathrm{ArCH}), 7.89(\mathrm{~m}$, $2 \mathrm{H}, 2 \times \mathrm{ArCH}), 7.37\left(\mathrm{~s}, 2 \mathrm{H}, \mathrm{SO}_{2} \mathrm{NH}_{2}\right), 4.45(\mathrm{t}, J=7.0 \mathrm{~Hz}, 2 \mathrm{H}$, $\left.\varepsilon \mathrm{CH}_{2}\right), 3.85\left(\mathrm{~s}, 2 \mathrm{H}, \beta \mathrm{CH}_{2}\right), 3.15\left(\mathrm{q}, J=6.7 \mathrm{~Hz}, 2 \mathrm{H}, \gamma \mathrm{CH}_{2}\right), 2.08-2.02$ (quint, $\left.J=6.9 \mathrm{~Hz}, 2 \mathrm{H}, \delta \mathrm{CH}_{2}\right) .{ }^{13} \mathrm{C}$ NMR $\left(500 \mathrm{MHz}, \mathrm{DMSO}-d_{6}\right): \delta_{\mathrm{C}}$ $166.2(\alpha \mathrm{C}=\mathrm{O}), 145.0(\mathrm{C} q), 143.1($ triazole $\mathrm{C} q), 133.9(\mathrm{C} q), 126.4(2$ $\times$ CHAr $), 125.3(2 \times$ CHAr $), 122.6($ triazole $\mathrm{CH}), 47.4\left(\varepsilon \mathrm{CH}_{2}\right), 36.3$ $\left(\gamma \mathrm{CH}_{2}\right), 29.5\left(\beta \mathrm{CH}_{2}\right.$ and $\left.\delta \mathrm{CH}_{2}\right), 29.4\left(\beta \mathrm{CH}_{2}\right.$ and $\left.\delta \mathrm{CH}_{2}\right)$. LRMS $\left(\mathrm{ESI}^{-}\right): m / z=402,400\left[\mathrm{M}-\mathrm{H} ;{ }^{81} \mathrm{Br},{ }^{79} \mathrm{Br}\right]^{-}$. HRMS (ESI): calcd for $\mathrm{C}_{13} \mathrm{H}_{16} \mathrm{BrN}_{5} \mathrm{O}_{3} \mathrm{~S}^{+}$, 402.0228; found, 402.0208 .

Tri-tert-butyl 2,2',2"-(10-(2-Oxo-2-((3-(4-(4-sulfamoylphenyl)-1H1,2,3-triazol-1-yl)propyl)amino)ethyl)-1,4,7,10-tetraazacyclododecane-1,4,7-triyl)triacetate (8). Compound 7 (109 mg, $0.21 \mathrm{mmol}), 6$ $(85 \mathrm{mg}, 0.21 \mathrm{mmol})$, and $\mathrm{K}_{2} \mathrm{CO}_{3}(58 \mathrm{mg}, 0.42 \mathrm{mmol})$ were dissolved in anhydrous $\mathrm{MeCN}(5 \mathrm{~mL})$, and the reaction mixture was stirred overnight at room temperature. The mixture was filtered through Celite and washed with $\mathrm{MeOH}$. The residue was purified by flash column chromatography (gradient 100\% DCM $\rightarrow$ 85:15 DCM/ $\mathrm{MeOH})$. Appropriate fractions were combined, and the product was isolated as a hygroscopic solid $(59.3 \mathrm{mg}, 33 \%) . R_{\mathrm{f}} 0.04(95: 5 \mathrm{DCM} /$ $\mathrm{MeOH}) .{ }^{1} \mathrm{H}$ NMR $\left(400 \mathrm{MHz}, \mathrm{DMSO}-d_{6}, 85^{\circ} \mathrm{C}\right): \delta_{\mathrm{H}} 8.63(\mathrm{~s}, 1 \mathrm{H}, \mathrm{CH}$ triazole), $8.17(\mathrm{t}, J=5.38 \mathrm{~Hz}, 1 \mathrm{H}, \mathrm{NH}), 7.98(\mathrm{~m}, 2 \mathrm{H}, 2 \times \mathrm{ArCH}), 7.91$ $(\mathrm{m}, 2 \mathrm{H}, 2 \times \mathrm{ArCH}), 7.20\left(\mathrm{~s}, 2 \mathrm{H}, \mathrm{SO}_{2} \mathrm{NH}_{2}\right), 4.45(\mathrm{t}, J=7.1 \mathrm{~Hz}, 2 \mathrm{H}$, $\left.\varepsilon \mathrm{CH}_{2}\right), 3.53(\mathrm{MeOH}), 3.19\left(\mathrm{~m}, 2 \mathrm{H}, \gamma \mathrm{CH}_{2}\right), 3.08\left(\mathrm{~s}, 6 \mathrm{H}, \tau \mathrm{CH}_{2}\right), 2.94$ $\left(\mathrm{dt}, J=42.0,5.2 \mathrm{~Hz}, 2 \mathrm{H}, \mathrm{CH}_{2} \mathrm{Aza}\right), 2.61\left(\mathrm{br}, 7 \mathrm{H}, \mathrm{CH}_{2} \mathrm{Aza}\right), 2.30(\mathrm{br}$, $7 \mathrm{H}, \mathrm{CH}_{2} \mathrm{Aza}$ ), 2.10 (quint, $\left.J=6.9 \mathrm{~Hz}, 2 \mathrm{H}, \delta \mathrm{CH}_{2}\right), 1.44(\mathrm{~s}, 9 \mathrm{H}, t \mathrm{Bu}$ ), $1.40(\mathrm{~s}, 18 \mathrm{H}, 2 \times \mathrm{tBu}) .{ }^{13} \mathrm{C}$ NMR $\left(75.5 \mathrm{MHz}, \mathrm{DMSO}-d_{6}\right): \delta_{\mathrm{C}} 172.5$ $(\mathrm{C}=\mathrm{O}), 172.2(2 \times \mathrm{C}=\mathrm{O}), 171.6(\mathrm{C}=\mathrm{O}), 145.0(\mathrm{C} q$ triazole $)$, 143.1 ( $\mathrm{C} q \mathrm{Ar}), 133.9$ ( $\mathrm{C} q \mathrm{Ar}), 126.4(2 \times \mathrm{ArCH}), 125.3(2 \times \mathrm{ArCH})$, 122.5 (CH triazole), 81.1 ( $\mathrm{Cq} \mathrm{tBu}), 80.9(2 \times \mathrm{Cq} \mathrm{tBu}), 69.8(\mathrm{MeOH})$, $60.18\left(\tau \mathrm{CH}_{2}\right), 55.7\left(\tau \mathrm{CH}_{2}\right), 55.3\left(\tau \mathrm{CH}_{2}\right), 54-49\left(\mathrm{CH}_{2} \mathrm{Aza}\right.$ in baseline $), 47.6\left(\varepsilon \mathrm{CH}_{2}\right), 36.0\left(\gamma \mathrm{CH}_{2}\right), 29.6\left(\delta \mathrm{CH}_{2}\right), 27.9\left(\beta \mathrm{CH}_{3}\right), 27.5$ $\left(\mathrm{CH}_{3} t \mathrm{Bu}\right)$. LRMS $\left(\mathrm{ESI}^{+}\right): m / z=836[\mathrm{M}+\mathrm{H}]^{+}$. HRMS (ESI): calcd for $\mathrm{C}_{39} \mathrm{H}_{65} \mathrm{~N}_{9} \mathrm{NaO}_{9} \mathrm{~S}^{+}$, 858.4518; found, 858.4513 .

2,2',2"-(10-(2-Oxo-2-((3-(4-(4-sulfamoylphenyl)-1H-1,2,3-triazol1-yl)propyl)amino)ethyl)-1,4,7,10-tetraazacyclododecane-1,4,7triyl)triacetic Acid (9). Compound $8(87.7 \mathrm{mg}, 0.1 \mathrm{mmol})$ was dissolved in 1:1 DCM/TFA $(8 \mathrm{~mL})$, and the solution was stirred at 40 ${ }^{\circ} \mathrm{C}$ for $3 \mathrm{~h}$. The reaction progress was monitored by LC-MS and RP18 TLC. When conversion was complete, the solvent was removed in vacuo and then coevaporated with water $(\times 3)$ followed by lyophilization. $R_{f} 0.76\left(50: 50 \mathrm{MeOH} / \mathrm{H}_{2} \mathrm{O}\right.$ RP-18 TLC). Samples for radiolabeling were purified using HPLC (isocratic 7:93 MeCN/ $\mathrm{H}_{2} \mathrm{O}+0.1 \%$ formic acid on a Waters Atlantis T3 C18 column (19 mm 
$\times 150 \mathrm{~mm}, 10 \mu \mathrm{M})$ at a flow rate of $12 \mathrm{~mL} / \mathrm{min}$ ). Product fractions were collected, and the solvent was removed in vacuo $(8.5 \mathrm{mg}, 52 \%$ HPLC recovery). ${ }^{1} \mathrm{H}$ NMR (500 MHz, DMSO- $\left.d_{6}\right): \delta_{\mathrm{H}} 8.69(\mathrm{~s}, 1 \mathrm{H}$, $\mathrm{CH}$ triazole $), 8.57(\mathrm{t}, J=5.2 \mathrm{~Hz}, 1 \mathrm{H}, \mathrm{NH}), 8.01(\mathrm{~m}, 2 \mathrm{H}, 2 \times \mathrm{ArCH})$, $7.90(\mathrm{~s}, 2 \mathrm{H}, 2 \times \mathrm{ArCH}), 7.38\left(\mathrm{~s}, 2 \mathrm{H}, \mathrm{SO}_{2} \mathrm{NH}_{2}\right), 4.48(\mathrm{t}, J=6.8 \mathrm{~Hz}$, $2 \mathrm{H}, \varepsilon \mathrm{CH}_{2}$ ), 4.1-3.0 (m, signals masked by broad $\mathrm{H}_{2} \mathrm{O}$ peak), 3.18 (q, $J=5.1 \mathrm{~Hz}, 2 \mathrm{H}, \gamma \mathrm{CH}_{2}$ ), 2.08 (quint, $2 \mathrm{H}, \delta \mathrm{CH}_{2}$ ). Correlations under the $\mathrm{H}_{2} \mathrm{O}$ peak were observed in the ${ }^{1} \mathrm{H}-{ }^{1} \mathrm{H}$ gCOSY and HSQC spectra. LRMS $\left(\mathrm{ESI}^{+}\right): m / z=668[\mathrm{M}+\mathrm{H}]^{+}$. HRMS (ESI): calcd for $\mathrm{C}_{27} \mathrm{H}_{42} \mathrm{~N}_{9} \mathrm{O}_{9} \mathrm{~S}^{+}$, 668.2821; found, 668.2819.

$\mathrm{N}$-[2-[2-[2-(2-Azidoethoxy)ethoxy]ethoxy]ethyl]-2-bromoacetamide (11). The title compound was synthesized from 11-azido-3,6,9trioxaundecanamine (10) $(450 \mathrm{mg}, 2.08 \mathrm{mmol})$ using general procedure 1 and isolated as a yellow oil $(0.54 \mathrm{~g}, 76 \%) . R_{\mathrm{f}} 0.35$ (95:5 DCM/MeOH). ${ }^{1} \mathrm{H}$ NMR $\left(500 \mathrm{MHz}, \mathrm{CDCl}_{3}\right): \delta_{\mathrm{H}} 6.92(\mathrm{~s}, 1 \mathrm{H}$, $\mathrm{NH}), 3.87\left(\mathrm{~s}, 2 \mathrm{H}, \beta \mathrm{CH}_{2}\right), 3.71-3.63\left(\mathrm{~m}, 10 \mathrm{H}, \varepsilon \mathrm{CH}_{2}, \zeta \mathrm{CH}_{2}\right), 3.59(\mathrm{t}, J$ $\left.=5.1 \mathrm{~Hz}, 2 \mathrm{H}, \delta \mathrm{CH}_{2}\right), 3.49\left(\mathrm{~m}, 2 \mathrm{H}, \gamma \mathrm{CH}_{2}\right), 3.39(\mathrm{t}, J=5.0 \mathrm{~Hz}, 2 \mathrm{H}$, $\left.\eta \mathrm{CH}_{2} \mathrm{~N}_{3}\right) .{ }^{13} \mathrm{C}$ NMR $\left(125 \mathrm{MHz}, \mathrm{CDCl}_{3}\right): \delta_{\mathrm{C}} 165.8(\alpha \mathrm{C}=\mathrm{O}),(70.9$, 70.8, 70.7, 70.5, 70.2, $\left.\varepsilon \mathrm{CH}, \zeta \mathrm{CH}_{2}\right), 69.5\left(\delta \mathrm{CH}_{2}\right), 50.8\left(\eta \mathrm{CH}_{2}\right), 40.1$ $\left(\gamma \mathrm{CH}_{2}\right), 29.2\left(\beta \mathrm{CH}_{2}\right)$. LRMS $\left(\mathrm{ESI}^{-}\right): m / z 339,337\left[\mathrm{M}-\mathrm{H},{ }^{81} \mathrm{Br}\right.$, $\left.{ }^{79} \mathrm{Br}\right]^{-}$. HRMS $\left(\mathrm{ESI}^{+}\right)$: calcd for $\mathrm{C}_{10} \mathrm{H}_{19}{ }^{79} \mathrm{BrN}_{4} \mathrm{O}_{4}^{+}, 339.0662$; found, 339.0684. The ${ }^{1} \mathrm{H}$ NMR data were in agreement with the data reported in the literature. ${ }^{66}$

2-Bromo-N-[[2-(2-[2-[4-(4-sulfamoylphenyl)-1H-1,2,3-triazol-1yl]ethoxy]ethoxy)ethoxy]methyl]acetamide (12). $\mathrm{CuSO}_{4}(2 \mathrm{mg}$, $0.007 \mathrm{mmol}$ ) and sodium ascorbate $(14 \mathrm{mg}, 0.071 \mathrm{mmol}$ ) were combined in $1 \mathrm{~mL}$ of $\mathrm{H}_{2} \mathrm{O}$ and added to a solution of azide 11 (264 $\mathrm{mg}, 0.78 \mathrm{mmol})$, alkyne 5 (128 mg, $0.71 \mathrm{mmol})$, and TBTA (4 mg, $0.007 \mathrm{mmol})$ in DMSO $(2 \mathrm{~mL})$. The mixture was left to stir at $45^{\circ} \mathrm{C}$, and the reaction was monitored by TLC. Once the reaction was complete, the reaction mixture was diluted with $\mathrm{H}_{2} \mathrm{O}$ and EtOAc, and the aqueous phase was extracted with EtOAc $(4 \times 30 \mathrm{~mL})$. The organic fractions were combined and washed with EDTA $(1.0 \mathrm{M})$ in ammonium hydroxide (28.0-30.0\%, $\mathrm{NH}_{3}$ basis) solution, dried $\left(\mathrm{Na}_{2} \mathrm{SO}_{4}\right)$, filtered, and purified by flash column chromatography (95:5 EtOAc/ $\mathrm{MeOH}$ or $\mathrm{DCM} / \mathrm{MeOH})$. The product was isolated as a yellow gum $(0.148 \mathrm{~g}, 40 \%) . R_{\mathrm{f}} 0.2(95: 5 \mathrm{DCM} / \mathrm{MeOH}), \mathrm{mp} 85-90$ ${ }^{\circ} \mathrm{C} .{ }^{1} \mathrm{H}$ NMR $\left(500 \mathrm{MHz}, \mathrm{DMSO}-d_{6}\right): \delta_{\mathrm{H}} 8.66(\mathrm{~s}, 1 \mathrm{H}$, triazole $\mathrm{CH})$, $8.28(\mathrm{brt}, J=5.90 \mathrm{~Hz}, 1 \mathrm{H}, \mathrm{NH}), 8.02(\mathrm{~m}, 2 \mathrm{H}, 2 \times \mathrm{ArCH}), 7.90(\mathrm{~m}$, $2 \mathrm{H}, 2 \times \mathrm{ArCH}), 7.36\left(\mathrm{~s}, 2 \mathrm{H}, \mathrm{SO}_{2} \mathrm{NH}_{2}\right), 4.60(\mathrm{t}, J=5.2 \mathrm{~Hz}, 2 \mathrm{H}$, $\left.\eta \mathrm{CH}_{2}\right), 3.88\left(\mathrm{t}, J=5.2 \mathrm{~Hz}, 2 \mathrm{H}, \zeta \mathrm{CH}_{2}\right), 3.84\left(\mathrm{~s}, 2 \mathrm{H}, \beta \mathrm{CH}_{2}\right), 3.58-3.45$ $\left(\mathrm{m}, 8 \mathrm{H}, \varepsilon \mathrm{CH}_{2}\right), 3.39\left(\mathrm{t}, J=5.7 \mathrm{~Hz}, 2 \mathrm{H}, \delta \mathrm{CH}_{2} \mathrm{NH}\right), 3.20(\mathrm{q}, J=5.67$ $\left.\mathrm{Hz}, 2 \mathrm{H}, \gamma \mathrm{CH}_{2}\right) .{ }^{13} \mathrm{C}$ NMR (500 MHz, DMSO- $\left.d_{6}\right): \delta_{\mathrm{C}} 166.0(\alpha \mathrm{C}=\mathrm{O})$, 144.9 (Cq Ar-triazole), $143.0\left(\mathrm{Cq} \mathrm{Ar}-\mathrm{SO}_{2} \mathrm{NH}_{2}\right), 133.9$ (Cq triazole), $126.3(2 \times \mathrm{ArCH}), 125.25(2 \times \mathrm{ArCH}), 122.84(\mathrm{CH}$ triazole $), 69.7-$ $69.5\left(\varepsilon \mathrm{CH}_{2}, 4 \mathrm{C}\right), 68.7\left(\delta \mathrm{CH}_{2}\right.$ or $\left.\zeta \mathrm{CH}_{2}\right), 68.6\left(\delta \mathrm{CH}_{2}\right.$ or $\left.\zeta \mathrm{CH}_{2}\right), 54.8$ (DCM), $49.7\left(\eta \mathrm{CH}_{2}\right), 48.6\left(\gamma \mathrm{CH}_{2}\right), 29.4\left(\beta \mathrm{CH}_{2}\right)$. LRMS $\left(\mathrm{ESI}^{+}\right): \mathrm{m} / z$ $=544,542\left[\mathrm{M}+\mathrm{Na},{ }^{81} \mathrm{Br},{ }^{79} \mathrm{Br}\right]^{+} ; 522,520\left[\mathrm{M}+\mathrm{H},{ }^{81} \mathrm{Br},{ }^{79} \mathrm{Br}\right]^{+}$. HRMS (ESI): calcd for $\mathrm{C}_{18} \mathrm{H}_{26}{ }^{79} \mathrm{BrN}_{5} \mathrm{NaO}_{6} \mathrm{~S}^{+}$, 542.0679; found, 542.0681 .

Tri-tert-butyl 2,2',2"-(10-(2-Oxo-14-(4-(4-sulfamoylphenyl)- $1 \mathrm{H}$ 1,2,3-triazol-1-yl)-6,9,12-trioxa-3-azatetradecyl)-1,4,7,10-tetraazacyclododecane-1,4,7-triyl)triacetate (13). Compound 12 (0.196 g, $0.37 \mathrm{mmol}$ ), 7 ( $253 \mathrm{mg}, 0.49 \mathrm{mmol}$ ), and $\mathrm{K}_{2} \mathrm{CO}_{3}(68 \mathrm{mg}, 0.49 \mathrm{mmol})$ were dissolved in anhydrous $\mathrm{MeCN}(8 \mathrm{~mL})$, and the reaction mixture was stirred at $60{ }^{\circ} \mathrm{C}$ for $3 \mathrm{~h}$. The mixture was filtered through Celite, washed $(\mathrm{MeCN})$, and concentrated, and the remaining residue was purified by column chromatography (90:10 DCM/MeOH). The fractions were monitored by HPLC, and positive fractions were combined to give the title compound as a hygroscopic off-white solid $(0.268 \mathrm{~g}, 76 \%) . R_{\mathrm{f}} 0.28(90: 10 \mathrm{DCM} / \mathrm{MeOH}) .{ }^{1} \mathrm{H}$ NMR $(500 \mathrm{MHz}$, DMSO- $\left.d_{6}\right): \delta_{\mathrm{H}} 8.67(\mathrm{~s}, 1 \mathrm{H}, \mathrm{CH}$ triazole $), 8.18(\mathrm{t}, J=5.9 \mathrm{~Hz}, 1 \mathrm{H}$, $\mathrm{NH}), 8.02(\mathrm{~m}, 2 \mathrm{H}, 2 \times \mathrm{ArCH}), 7.90(\mathrm{~m}, 2 \mathrm{H}, 2 \times \mathrm{ArCH}), 7.37(\mathrm{~s}, 2 \mathrm{H}$, $\left.\mathrm{SO}_{2} \mathrm{NH}_{2}\right), 4.59\left(\mathrm{t}, J=5.1 \mathrm{~Hz}, 2 \mathrm{H}, \eta \mathrm{CH}_{2}\right), 3.88(\mathrm{t}, J=5.1 \mathrm{~Hz}, 2 \mathrm{H}$, $\left.\zeta \mathrm{CH}_{2}\right), 3.50\left(\mathrm{~m}, 8 \mathrm{H}, \varepsilon \mathrm{CH}_{2}\right), 3.41\left(\mathrm{t}, J=5.94 \mathrm{~Hz}, 2 \mathrm{H}, \delta \mathrm{CH}_{2}\right), 3.21(\mathrm{~m}$, $2 \mathrm{H}, \gamma \mathrm{CH}_{2}$ ), 3.1-2.0 (br, m, $\left.24 \mathrm{H}, \mathrm{Aza} \mathrm{CH}_{2}, \beta \mathrm{CH}_{2}, 3 \times \tau \mathrm{CH}_{2}\right), 1.43(\mathrm{~s}$, $9 \mathrm{H}, t \mathrm{Bu}), 1.41(\mathrm{~s}, 18 \mathrm{H}, 2 \times t \mathrm{Bu}) .{ }^{13} \mathrm{C}$ NMR $\left(125 \mathrm{MHz}, \mathrm{DMSO}-d_{6}\right): \delta_{\mathrm{C}}$ $172.5(\mathrm{C}=\mathrm{O}), 172.1 \quad(2 \times \mathrm{C}=\mathrm{O}), 171.6(\mathrm{C}=\mathrm{O}), 144.9(\mathrm{C} q$ triazole), 143.1 ( $\mathrm{C} q \mathrm{Ar}), 134.0(\mathrm{Cq} \mathrm{Ar}), 126.3(2 \times \mathrm{ArCH}), 125.2(2$ $\times \mathrm{ArCH}), 122.8(\mathrm{CH}$ triazole $), 81.1(\mathrm{C} q t \mathrm{Bu}), 80.9(2 \times \mathrm{C} q t \mathrm{Bu})$,
69.6-69.5 $\left(\varepsilon \mathrm{CH}_{2}, \beta \mathrm{CH}_{2}\right), 68.8\left(\zeta \mathrm{CH}_{2}\right), 68.5\left(\delta \mathrm{CH}_{2}\right), 59.7\left(\tau \mathrm{CH}_{2}\right)$, $55.7\left(\tau \mathrm{CH}_{2}\right), 55.3\left(\tau \mathrm{CH}_{2}\right), 49.7\left(\eta \mathrm{CH}_{2}\right), 38.5\left(\gamma \mathrm{CH}_{2}\right), 27.5\left(\mathrm{CH}_{3}\right.$ $t \mathrm{Bu}), \mathrm{CH}_{2}$ Aza peaks masked in baseline. LRMS $\left(\mathrm{ESI}^{+}\right): \mathrm{m} / z=954[\mathrm{M}$ $+\mathrm{H}]^{+}$. HRMS (ESI): calcd for $\mathrm{C}_{44} \mathrm{H}_{75} \mathrm{~N}_{9} \mathrm{NaO}_{12} \mathrm{~S}^{+}$, 976.5148; found, 976.5155.

2-[4,10-Bis(carboxymethyl)-7-[[[2-[2-(2-[2-[4-(4-sulfamoylphenyl)-1H-1,2,3-triazol-1-yl]ethoxy]ethoxy)ethoxy]ethyl]carbamoyl]methyl]-1,4,7,10-tetraazacyclododecan-1-yl]acetic Acid (14). Compound $13(0.219 \mathrm{mg}, 0.23 \mathrm{mmol})$ was dissolved in formic acid or 1:1 TFA/DCM $(10 \mathrm{~mL})$, and the solution was stirred at $60{ }^{\circ} \mathrm{C}$. The reaction was monitored by HPLC. Upon completion, water $(10 \mathrm{~mL})$ was added, and the solvent was removed in vacuo and then coevaporated with water $(\times 3)$ followed by lyophilization. The sample was purified by reversed-phase column chromatography using a gradient of $100 \% \mathrm{H}_{2} \mathrm{O} \rightarrow 95: 5 \mathrm{MeOH} / \mathrm{H}_{2} \mathrm{O}$, and the product was isolated as a hygroscopic white gum $(144 \mathrm{mg}, 80 \%) . R_{\mathrm{f}} 0.53(50: 50$ $\mathrm{MeOH} / \mathrm{H}_{2} \mathrm{O}$ RP-18 TLC). Samples were further purified via HPLC prior to radiolabeling (isocratic 10:90 MeCN/ $\mathrm{H}_{2} \mathrm{O}+0.1 \%$ formic acid on a Waters Atlantis T3 C18 column $(19 \mathrm{~mm} \times 150 \mathrm{~mm}, 10 \mu \mathrm{m})$ at a flow rate of $12 \mathrm{~mL} / \mathrm{min}$ ). The product fractions were collected, and the solvent was removed in vacuo (19\%). ${ }^{1} \mathrm{H}$ NMR $(500 \mathrm{MHz}$, DMSO- $\left.d_{6}\right): \delta_{\mathrm{H}} 8.67(\mathrm{~s}, 1 \mathrm{H}, \mathrm{CH}$ triazole $), 8.17(\mathrm{br}, 1 \mathrm{H}, \mathrm{NH}), 8.02(\mathrm{~m}$, $2 \mathrm{H}, 2 \times \mathrm{ArCH}), 7.90(\mathrm{~m}, 2 \mathrm{H}, 2 \times \mathrm{ArCH}), 7.38\left(\mathrm{~s}, 2 \mathrm{H}, \mathrm{SO}_{2} \mathrm{NH}_{2}\right), 4.60$ $\left(\mathrm{t}, J=5.0 \mathrm{~Hz}, 2 \mathrm{H}, \eta \mathrm{CH}_{2}\right), 3.88\left(\mathrm{t}, J=5.3 \mathrm{~Hz}, 2 \mathrm{H}, \zeta \mathrm{CH}_{2}\right)$, the remaining signals were masked by the broad $\mathrm{H}_{2} \mathrm{O}$ peak. Correlations were observed in the ${ }^{1} \mathrm{H}-{ }^{1} \mathrm{H}$ gCOSY and HSQC spectra. LRMS $\left(\mathrm{ESI}^{+}\right): m / z 786[\mathrm{M}+\mathrm{H}]^{+}$. HRMS (ESI): calcd for $\mathrm{C}_{32} \mathrm{H}_{51} \mathrm{~N}_{9} \mathrm{NaO}_{12} \mathrm{~S}^{+}$, 808.3281; found, 808.3278.

2,2',2"-(10-(2-Oxo-2-((3-(4-(4-sulfamoylphenyl)-1H-1,2,3-triazol1-yl)propyl)amino)ethyl)-1,4,7,10-tetraazacyclododecane-1,4,7triyl)triacetic Acid Gallium Complex ( ${ }^{\text {nat }} \mathrm{Ga}-1$ ). Compound 9 (48 mg, $0.071 \mathrm{mmol}$ ) was treated as per general procedure 2 to give the title compound as a hygroscopic white solid. LRMS $\left(\mathrm{ESI}^{-}\right): m / z=734[\mathrm{M}$ $-\mathrm{H}]^{-}$. HRMS (ESI): calcd for $\mathrm{C}_{27} \mathrm{H}_{38} \mathrm{GaN}_{9} \mathrm{NaO}_{9} \mathrm{~S}^{+}$, 756.1661; found, 756.1660 .

2-[4,10-Bis(carboxymethyl)-7-[([2-[2-(2-[2-[4-(4-sulfamoylphenyl)-1H-1,2,3-triazol-1-yl]ethoxy]ethoxy)ethoxy]ethyl]carbamoyl)methyl]-1,4,7,10-tetraazacyclododecan-1-yl]acetic Acid Gallium Complex ( $\left.{ }^{\text {nat }} \mathrm{Ga}-2\right)$. Compound $14(50 \mathrm{mg}, 0.064 \mathrm{mmol})$ was treated as per general procedure 2 to give the title compound as a hygroscopic white solid. $R_{\mathrm{f}} 0.65$ (RP-18 TLC, 60:40 $\left.\mathrm{H}_{2} \mathrm{O} / \mathrm{MeOH}\right)$. LRMS (ESI ${ }^{+}$): $m / z 852[\mathrm{M}+\mathrm{H}]^{+}$. HRMS (ESI): calcd for $\mathrm{C}_{32} \mathrm{H}_{49} \mathrm{GaN}_{9} \mathrm{O}_{12} \mathrm{~S}^{+}$, 852.2472; found, 852.2460.

Cell Culture. Human MDA-MB-231 breast cancer cells (ATCC26) for toxicity studies were cultured in Roswell Park Memorial Institute (RPMI) 1640 medium supplemented with $10 \%$ fetal bovine serum (FBS), 100 units $/ \mathrm{mL}$ penicillin, and $100 \mu \mathrm{g} / \mathrm{mL}$ streptomycin at $37^{\circ} \mathrm{C}$ and $5 \% \mathrm{CO}_{2}$. Cells were seeded at $3 \times 10^{4}$ cells/well $(200 \mu \mathrm{L}$, RPMI-1640) and allowed to grow for $24 \mathrm{~h}$ before being exposed to the compound of interest. Untreated cells were used as a control. HCT116 human colorectal carcinoma cells (ATCC CCL-247) stably expressing a CA IX-targeting shRNA (shCA IX) or nontargeting shRNA (shNT) construct established as described previously ${ }^{61}$ were routinely cultured in Dulbecco's modified Eagle's medium (DMEM) supplemented with $10 \%$ FBS at $37^{\circ} \mathrm{C}$.

Cell Proliferation Assay. Compounds were dissolved in RPMI medium to a final concentration of $1 \mathrm{mM}$, and linear dilutions ranging from $1 \mathrm{mM}$ to $1 \mu \mathrm{M}$ were carried out in culture medium. After $24 \mathrm{~h}$ of treatment at $37^{\circ} \mathrm{C}$ and $5 \% \mathrm{CO}_{2}$, MTT $(20 \mu \mathrm{L}, 5 \mathrm{mg} / \mathrm{mL})$ was added. After $3 \mathrm{~h}$, SDS $(50 \mu \mathrm{L}, 20 \%(\mathrm{w} / \mathrm{v})$ SDS in $0.01 \mathrm{M} \mathrm{HCl})$ was added, and the plates were left overnight before being read by a SpectraMax fluorescence plate reader (Molecular Devices) at $570 \mathrm{~nm}$. Experiments were performed in triplicate and, where possible, were repeated three times. Values were determined using the GraphPad Prism software (www.graphpad.com).

Radiolabeling. Radiolabeling with ${ }^{67} \mathrm{Ga} .\left[{ }^{67} \mathrm{Ga}\right] \mathrm{GaCl}_{3}$ in $0.1 \mathrm{M}$ $\mathrm{HCl}$ was prepared from commercial $\left[{ }^{67} \mathrm{Ga}\right]$ citrate for injection (Lantheus) via standard conversion methods. ${ }^{67}$ In an acid-washed microcentrifuge tube, the DOTA complex $\left(25 \mu \mathrm{L}, 1 \mathrm{mM} \mathrm{H}_{2} \mathrm{O}\right)$ and sodium acetate buffer $(100 \mu \mathrm{L}, 0.1 \mathrm{M}, \mathrm{pH} 4.3)$ were combined, and 
the solution was agitated. ${ }^{67} \mathrm{GaCl}_{3}(18-21 \mathrm{MBq}$ in $0.1 \mathrm{M} \mathrm{HCl})$ was added, and the solution was heated at $95{ }^{\circ} \mathrm{C}$ for $10 \mathrm{~min}$ using a solidstate heating block. The sample was stirred via convection. Once the reaction was complete, a sample $(20 \mu \mathrm{L}, \sim 3 \mathrm{MBq})$ was analyzed by HPLC, and the radiochemical purity was noted. The solutions were purified by HPLC (Atlantis T3, $10 \mathrm{~mm} \times 250 \mathrm{~mm}, 5 \mu \mathrm{m}$, flow rate 3 $\mathrm{mL} / \mathrm{min}$ ) or rapid reversed-phase C-18 SPE (washed with copious amounts of $\mathrm{H}_{2} \mathrm{O}$ and compounds eluted in 50:50 EtOH/ $\mathrm{H}_{2} \mathrm{O}$ ).

Stability of $\left[{ }^{67} \mathrm{Ga}\right]-1$ and $\left[{ }^{67} \mathrm{Ga}\right]-2$ versus Human Serum. Human serum $(150 \mu \mathrm{L})$ was placed in a previously acid-washed $0.5 \mathrm{~mL}$ microcentrifuge tube. To this was added 10X PBS concentrate (15 $\mu \mathrm{L})$, water $(60 \mu \mathrm{L})$, and the radiocomplex ( $75 \mu \mathrm{L}$ in water, $0.24-0.28$ $\mathrm{MBq})$. The mixture was agitated via a bench vortex mixer and then incubated at $37.5^{\circ} \mathrm{C}$ for the course of the study. Aliquots $(5-15 \mu \mathrm{L})$ were injected onto a Phenomenex Biosep SEC-S 3000 column (300 $\mathrm{mm} \times 7.8 \mathrm{~mm}$ i.d., $5 \mu \mathrm{m}$, pore size $290 \AA$ ) with a mobile phase of 50 $\mathrm{mM}$ sodium phosphate and $300 \mathrm{mM} \mathrm{NaCl}(\mathrm{pH} 7.0,0.2 \mu \mathrm{m}$ filtered) at $1 \mathrm{~mL} / \mathrm{min}$ on an HPLC system. Serum uptake was assessed as a percentage of the total activity in the chromatogram.

Stability of $\left[{ }^{67} \mathrm{Ga}\right]-1$ and $\left[{ }^{67} \mathrm{Ga}\right]-2$ in Phosphate-Buffered Saline. In a previously acid-washed $0.5 \mathrm{~mL}$ microcentrifuge tube, $10 \times$ PBS concentrate $(20 \mu \mathrm{L})$, water $(160 \mu \mathrm{L})$, and the radiocomplex $(20 \mu \mathrm{L}$ in water, $0.2-0.23 \mathrm{MBq}$ ) were combined. The solution was agitated and then incubated at $37.5^{\circ} \mathrm{C}$ for the course of the study. Aliquots $(5-50$ $\mu \mathrm{L})$ were injected onto a Waters Atlantis T3 C18 column $(150 \mathrm{~mm} \times$ $4.6 \mathrm{~mm}$ i.d., $3 \mu \mathrm{m}$ ) with a mobile phase of $16: 84 \mathrm{MeCN} / \mathrm{ammonium}$ formate buffer $(120 \mathrm{mM}, \mathrm{pH} 4.43,0.2 \mu \mathrm{m}$ filtered) at $0.6 \mathrm{~mL} / \mathrm{min}$ on a HPLC system. Stability was assessed as a percentage of the parent radiocomplex.

Radiolabeling with ${ }^{68} \mathrm{Ga}$. The reaction progress was monitored by radio-HPLC equipped with an Inertsil ODS C18 column $(5 \mu \mathrm{m}, 4.6$ $\mathrm{mm} \times 250 \mathrm{~mm})$ using a gradient method $\left(100 \% \mathrm{H}_{2} \mathrm{O} \rightarrow 100 \% \mathrm{MeCN}\right.$ over $17 \mathrm{~min}, 1 \mathrm{~mL} / \mathrm{min}$ ). Sodium acetate or ammonium acetate buffer (3 M, $400 \mu \mathrm{L}, \mathrm{pH} 4.3-4.5$ ) was combined with $\sim 800 \mathrm{MBq}$ of ${ }^{68} \mathrm{Ga}$ in aqueous $\mathrm{HCl}(0.6 \mathrm{M}, \sim 1.2 \mathrm{~mL})$, which was eluted from an iThemba $1480 \mathrm{MBq}{ }^{68} \mathrm{Ge} /{ }^{68} \mathrm{Ga}$ generator. Compound 14 in $\mathrm{H}_{2} \mathrm{O}(40 \mu \mathrm{L}, 1$ $\mathrm{mM}$ ) was added, and the solution was mixed by Eppendorf pipet ( $\mathrm{pH}$ $\sim 4.5$ ) and then heated at $99{ }^{\circ} \mathrm{C}$ for $10 \mathrm{~min}$. Reaction mixtures were analyzed by radio-HPLC, and the radiochemical purity was consistently $>95 \%$. The specific activity of $\left[{ }^{68} \mathrm{Ga}\right]-2$ at the time of radiolabeling was $\sim 20 \mathrm{MBq} / \mathrm{nmol}(800 \mathrm{MBq} / 40 \mathrm{nmol})$. Small-animal PET imaging studies with $\left[{ }^{68} \mathrm{Ga}\right]-2$ were carried out between 1 and 2.5 $\mathrm{h}$ post radiolabeling of $\mathbf{1 4} \rightarrow\left[{ }^{68} \mathrm{Ga}\right]-\mathbf{2}$. No further purification was carried out prior to imaging. Samples $(\sim 3.7 \mathrm{MBq})$ were diluted in $0.9 \%$ saline solution prior to injection.

CA Inhibition Assay. An Applied Photophysics stopped-flow instrument was used for assaying the CA-catalyzed $\mathrm{CO}_{2}$ hydration activity. ${ }^{58} \mathrm{IC}_{50}$ values were obtained from dose-response curves working at seven different concentrations of test compound by nonlinear least-squares fitting using GraphPad Prism; values represent means of at least three different determinations as described previously. ${ }^{39}$ The inhibition constants $\left(K_{\mathrm{i}}\right)$ were then derived using the Cheng-Prusoff equation: $K_{\mathrm{i}}=\mathrm{IC}_{50} /\left(1+[\mathrm{S}] / K_{\mathrm{m}}\right)$, where $[\mathrm{S}]$ is the $\mathrm{CO}_{2}$ concentration at which the measurement was carried out and $K_{\mathrm{m}}$ is the concentration of substrate at which the enzyme activity is halfmaximal. All of the enzymes used were recombinant, produced in Escherichia coli as reported earlier. ${ }^{6,69}$ The following concentrations of enzymes were used in the assay: hCA I, $10.4 \mathrm{nM}$; hCA II, $8.3 \mathrm{nM}$; hCA IX, $8.0 \mathrm{nM}$; hCA XII, $12.4 \mathrm{nM}$.

Animal Model. Animal experiments were performed using adult NMRI- $n u$ mice. Animal facilities and experiments were in accordance with local institutional guidelines for animal welfare and were approved by the Maastricht University Animal Ethical Committee (no. 2014-020). HCT116 cells stably expressing either a CA IXtargeting shRNA (shCA IX) $(n=10)$ or CA IX-nontargeting shRNA $(\operatorname{shNT})(n=10)$ construct established as described previously ${ }^{61}$ were resuspended in BD Matrigel Basement Membrane Matrix (BD Biosciences) and injected $\left(10^{6}\right)$ subcutaneously into the lateral flank of the animal.
Image Acquisition. Once tumors reached a volume between 180 and $300 \mathrm{~mm}^{3}$, animals were intravenously injected via the lateral tail vein with $\sim 3.7 \mathrm{MBq}$ of the ${ }^{68}$ Ga-labeled sulfonamide compound diluted in $0.9 \%$ saline solution via an IV line flushed with $10 \%$ heparin saline solution. For PET and CT scans, animals receiving only a PET scan were anesthetized with isoflurane (induction $4 \%$, maintenance 12\%); animals receiving both PET and CT scans were anesthetized with an intraperitoneal injection of a $100 \mathrm{mg} / \mathrm{kg}$ ketamine $/ 10 \mathrm{mg} / \mathrm{kg}$ xylazine mixture. PET image acquisition was performed using a Focus 120 microPET (Siemens Medical Solutions USA, Inc.). Animals receiving only a PET scan underwent a 9 min emission scan at $1,2,3$, and $4 \mathrm{~h}$ p.i., whereas animals receiving both PET and CT scans underwent a $15 \mathrm{~min}$ emission scan $1 \mathrm{~h}$ p.i. The OSEM-3Dreconstructed PET images were viewed and analyzed using the PMOD software (PMOD Technologies Ltd.). Activity data $(\mathrm{Bq} / \mathrm{mL})$ were obtained by manually delineating volumes of interest (VOIs) in the PET images for mice that received only a PET scan or in the fused $\mathrm{PET} / \mathrm{CT}$ images for mice that received both PET and CT scans, using the PMOD software. The tumor itself was delineated as tumor VOI $(\mathrm{T})$, whereas the heart outflow area was delineated as blood VOI (B). Standardized uptake values (SUVs) were calculated by correcting the activity data for the ${ }^{68} \mathrm{Ga}$ injected dose, decay toward injection time, and weight of the animal. Data were quantified by calculating the $\mathrm{T} / \mathrm{B}$ activity ratios (TBRs). CT image acquisition was performed using the SmART system (X-RAD 225CX; Precision X-ray, North Branford, CT, USA). Tumor volume at time of scanning was determined by delineating the tumor on the CT image using the PMOD software.

Western Blot. Samples from tumors were minced, and proteins were isolated using RIPA buffer completed with a protease inhibitor cocktail (complete EDTA-free; Roche). Bradford assay (BioRad) was performed for protein quantification. Proteins were separated on a $10 \%$ SDS-PAGE gel and blotted onto a nitrocellulose membrane (GE Healthcare) by electrotransfer. Membranes were blocked in 5\% nonfat dry milk and probed overnight with mouse anti-CA IX monoclonal antibody (M75, kindly provided by S. Pastorekova, Institute of Virology, Slovak Academy of Science, Bratislava, Slovak Republic) and mouse anti- $\beta$-actin monoclonal antibody (Cell Signaling). Subsequently, membranes were probed with horseradish peroxidase-linked horse anti-mouse IgG antibodies (Cell Signaling), which were detected with Western blot detection reagents (Thermo Fisher Scientific).

Immunofluorescence. Mice were injected intravenously with the hypoxia marker pimonidazole $1 \mathrm{~h}$ before sacrifice. After sacrifice, tumors were collected and sections were made. The sections were fixed with cold acetone, and nonspecific binding was blocked using $1 \%$ normal goat serum at room temperature for $30 \mathrm{~min}$. The sections were incubated overnight at $4{ }^{\circ} \mathrm{C}$ with rabbit anti-CA IX polyclonal antibody (1:1000, Novus Biologicals) and fluorescein isothiocyanateconjugated mouse antipimonidazole monoclonal antibody (1:100, Hypoxyprobe, Bioconnect). Subsequently, the sections were incubated at room temperature for $1 \mathrm{~h}$ with Alexa Fluor 594-conjugated goat anti-rabbit secondary antibody (1:500, Invitrogen). Mounting was done using fluorescence mounting medium (Dako).

Autoradiography. Tumor sections $(30 \mu \mathrm{m})$ were made using a cyrotome (Leica) and placed on high-resolution phosphorimaging plates (Storage Phosphor Screen BAS-IP SR 2040 E Super Resolution, GE Healthcare) overnight. The plates were read using a Typhoon FLA 7000 laser scanner (GE Healthcare). Signal intensities were determined using the ImageQuant TL software (GE Healthcare) and normalized per animal to the respective ID.

Statistics. All of the statistical analyses were performed using GraphPad Prism version 5.03. Unpaired Student's $t$ test was used to determine the statistical significance of differences between two independent groups of variables.

\section{ASSOCIATED CONTENT}

\section{Supporting Information}

The Supporting Information is available free of charge on the ACS Publications website at DOI: 10.1021/acs.jmedchem.6b00623. 
${ }^{1} \mathrm{H}$ and ${ }^{13} \mathrm{C}$ NMR spectra for compounds and radiotraces (PDF)

$$
\text { SMILES strings (CSV) }
$$

\section{AUTHOR INFORMATION}

\section{Corresponding Authors}

*S.-A.P.: Telephone: +61 73735 7825. E-mail: s.poulsen@ griffith.edu.au.

*L.D.: Telephone: +31 43388 2909. E-mail: ludwig.dubois@ maastrichtuniversity.nl.

\section{Author Contributions}

${ }^{\#}$ D.S. and R.N. contributed equally.

Notes

The authors declare no competing financial interest.

\section{ACKNOWLEDGMENTS}

This work was funded by the Cancer Council Queensland (Project APP1058222) and the Australian Institute of Nuclear Science and Engineering (AINSE) (Projects ALNGRA15021 and ALNGRA13520). We thank the Australian Research Council (FT10100185 to S.-A.P.). The authors acknowledge financial support from the Dutch Cancer Society (KWF UM 2012-5394 and KWF MAC 2013-6089). HCT116 human colorectal carcinoma cells (ATCC CCL-247) stably expressing a shCA IX or shNT construct were kindly provided by Adrian Harris of the Weatherall Institute of Molecular Medicine, University of Oxford, John Radcliffe Hospital, Oxford, U.K.

\section{ABBREVIATIONS USED}

$\mathrm{CA}$, carbonic anhydrase; $\mathrm{CDCl}_{3}$, deuterated chloroform; $\mathrm{CL}_{\text {int }}$ intrinsic clearance value; $\mathrm{CT}$, computed tomography; $\mathrm{CuAAC}$, copper-catalyzed azide-alkyne cycloaddition; DOTA, 1,4,7,10tetraazacyclododecane- $N, N^{\mathrm{I}}, N^{\mathrm{II}}, N^{\mathrm{III}}-1,4,7,10$-tetraacetic acid; DIPEA, diisopropylethylamine; DMEM, Dulbecco's modified Eagle's medium; DTPA, diethylenetriaminepentaacetic acid; $E_{\mathrm{H}}$, predicted in vivo hepatic extraction ratio; FBS, fetal bovine serum; FDA, U.S. Food and Drug Administration; $\mathrm{Hb}$, hemoglobin; HIF- $1 \alpha$, hypoxia inducible factor- $1 \alpha$; h p.i., hour post injection; ID, injected dose; ITLC-SC, silica gel instant thin-layer chromatography; LRMS, low-resolution mass spectrometry; $\mathrm{MeOH}$, methanol; MTT, (3-(4,5-dimethylthiazol-2yl)-2,5-diphenyltetrazolium bromide); $P_{\text {app }}$, membrane permeability; p.i, post injection; RCP, radiochemical purity; RPHPLC, reversed-phase high-performance liquid chromatography; RIPA, radioimmunoprecipitation assay; RPMI, Roswell Park Memorial Institute; shCA IX, CA IX-knockdown tumor; shNT, CA IX-expressing tumor; SPE, solid-phase extraction; SPECT, single-photon-emission computed tomography; $t_{1 / 2}$, half-life; TBR, tumor-to-blood ratio; TBTA, tris(benzyltriazolylmethyl)amine

\section{REFERENCES}

(1) Hanahan, D.; Weinberg, R. A. Hallmarks of Cancer: The Next Generation. Cell 2011, 144, 646-674.

(2) Horsman, M. R.; Mortensen, L. S.; Petersen, J. B.; Busk, M.; Overgaard, J. Imaging hypoxia to improve radiotherapy outcome. Nat. Rev. Clin. Oncol. 2012, 9, 674-687.

(3) Rockwell, S.; Dobrucki, I. T.; Kim, E. Y.; Marrison, S. T.; Vu, V. T. Hypoxia and radiation therapy: Past history, ongoing research, and future promise. Curr. Mol. Med. 2009, 9, 442-458.

(4) Peeters, S. G. J. A.; Zegers, C. M. L.; Biemans, R.; Lieuwes, N. G.; van Stiphout, R. G. P. M.; Yaromina, A.; Sun, J. D.; Hart, C. P.; Windhorst, A. D.; van Elmpt, W.; Dubois, L. J.; Lambin, P. TH-302 in
Combination with Radiotherapy Enhances the Therapeutic Outcome and Is Associated with Pretreatment $[18 \mathrm{~F}] \mathrm{HX} 4$ Hypoxia PET Imaging. Clin. Cancer Res. 2015, 21, 2984-2992.

(5) Peeters, S. G. J. A.; Zegers, C. M. L.; Lieuwes, N. G.; van Elmpt, W.; Eriksson, J.; van Dongen, G. A. M. S.; Dubois, L.; Lambin, P. A Comparative Study of the Hypoxia PET Tracers [18F]HX4, [18F]FAZA, and [18F]FMISO in a Preclinical Tumor Model. Int. J. Radiat. Oncol., Biol., Phys. 2015, 91, 351-359.

(6) Zegers, C. M. L.; van Elmpt, W.; Reymen, B.; Even, A. J. G.; Troost, E. G. C.; Öllers, M. C.; Hoebers, F. J. P.; Houben, R. M. A.; Eriksson, J.; Windhorst, A. D.; Mottaghy, F. M.; De Ruysscher, D.; Lambin, P. In Vivo Quantification of Hypoxic and Metabolic Status of NSCLC Tumors Using [18F]HX4 and [18F]FDG-PET/CT Imaging. Clin. Cancer Res. 2014, 20, 6389-6397.

(7) Zegers, C. M. L.; van Elmpt, W.; Szardenings, K.; Kolb, H.; Waxman, A.; Subramaniam, R. M.; Moon, D. H.; Brunetti, J. C.; Srinivas, S. M.; Lambin, P.; Chien, D. Repeatability of hypoxia PET imaging using $[18 \mathrm{~F}] \mathrm{HX} 4$ in lung and head and neck cancer patients: a prospective multicenter trial. Eur. J. Nucl. Med. Mol. Imaging 2015, 42, $1840-1849$.

(8) van Loon, J.; Janssen, M. H. M.; Öllers, M.; Aerts, H. J. W. L.; Dubois, L.; Hochstenbag, M.; Dingemans, A.-M. C.; Lalisang, R.; Brans, B.; Windhorst, B.; van Dongen, G. A.; Kolb, H.; Zhang, J.; De Ruysscher, D.; Lambin, P. PET imaging of hypoxia using [18F]HX4: a phase I trial. Eur. J. Nucl. Med. Mol. Imaging 2010, 37, 1663-1668.

(9) Greer, S. N.; Metcalf, J. L.; Wang, Y.; Ohh, M. The updated biology of hypoxia-inducible factor. EMBO J. 2012, 31, 2448-2460.

(10) Potter, C. P. S.; Harris, A. L. Diagnostic, prognostic and therapeutic implications of carbonic anhydrases in cancer. Br. J. Cancer 2003, 89, 2-7.

(11) Kaluz, S.; Kaluzová, M.; Liao, S.-Y.; Lerman, M.; Stanbridge, E. J. Transcriptional control of the tumor- and hypoxia-marker carbonic anhydrase 9: A one transcription factor (HIF-1) show? Biochim. Biophys. Acta, Rev. Cancer 2009, 1795, 162-172.

(12) Bao, B.; Groves, K.; Zhang, J.; Handy, E.; Kennedy, P.; Cuneo, G.; Supuran, C. T.; Yared, W.; Rajopadhye, M.; Peterson, J. D. In Vivo Imaging and Quantification of Carbonic Anhydrase IX Expression as an Endogenous Biomarker of Tumor Hypoxia. PLoS One 2012, 7, e50860.

(13) Potter, C.; Harris, A. L. Hypoxia inducible carbonic anhydrase IX, marker of tumour: hypoxia, survival pathway and therapy target. Cell Cycle 2004, 3, 159-162.

(14) van Kuijk, S. J. A.; Yaromina, A.; Houben, R.; Niemans, R.; Lambin, P.; Dubois, L. J. Prognostic significance of carbonic anhydrase IX expression in cancer patients: A meta-analysis. Front. Oncol. 2016, 6, 69.

(15) Neri, D.; Supuran, C. T. Interfering with $\mathrm{pH}$ regulation in tumours as a therapeutic strategy. Nat. Rev. Drug Discovery 2011, 10, $767-777$.

(16) Lawrentschuk, N.; Lee, F. T.; Jones, G.; Rigopoulos, A.; Mountain, A.; O'Keefe, G.; Papenfuss, A. T.; Bolton, D. M.; Davis, I. D.; Scott, A. M. Investigation of hypoxia and carbonic anhydrase IX expression in a renal cell carcinoma xenograft model with oxygen tension measurements and 124I-cG250 PET/CT. Urol. Oncol-Semin. Ori. 2011, 29, 411-420.

(17) Carlin, S.; Khan, N.; Ku, T.; Longo, V. A.; Larson, S. M.; SmithJones, P. M. Molecular Targeting of Carbonic Anhydrase IX in Mice with Hypoxic HT29 Colorectal Tumor Xenografts. PLoS One 2010, 5, e10857.

(18) Pastorek, J.; Pastorekova, S. Hypoxia-induced carbonic anhydrase IX as a target for cancer therapy: From biology to clinical use. Semin. Cancer Biol. 2015, 31, 52-64.

(19) Swietach, P.; Vaughan-Jones, R. D.; Harris, A. L. Regulation of tumor $\mathrm{pH}$ and the role of carbonic anhydrase 9. Cancer Metastasis Rev. 2007, 26, 299-310.

(20) Parks, S. K.; Chiche, J.; Pouyssegur, J. pH control mechanisms of tumor survival and growth. J. Cell. Physiol. 2011, 226, 299-308.

(21) Oosterwdk, E.; Ruiter, D. J.; Hoedemaeker, P. J.; Pauwels, E. K. J.; Jonas, U.; Zwartendijk, I.; Warnaar, S. O. Monoclonal antibody G 
250 recognizes a determinant present in renal-cell carcinoma and absent from normal kidney. Int. J. Cancer 1986, 38, 489-494.

(22) Sneddon, D.; Poulsen, S.-A. Agents described in the Molecular Imaging and Contrast Agent Database for imaging carbonic anhydrase IX expression. J. Enzyme Inhib. Med. Chem. 2014, 29, 753-763.

(23) Dubois, L. J.; Niemans, R.; van Kuijk, S. J. A.; Panth, K. M.; Parvathaneni, N.-K.; Peeters, S. G. J. A.; Zegers, C. M. L.; Rekers, N. H.; van Gisbergen, M. W.; Biemans, R.; Lieuwes, N. G.; Spiegelberg, L.; Yaromina, A.; Winum, J.-Y.; Vooijs, M.; Lambin, P. New ways to image and target tumour hypoxia and its molecular responses. Radiother. Oncol. 2015, 116, 352-357.

(24) Dubois, L.; Douma, K.; Supuran, C. T.; Chiu, R. K.; van Zandvoort, M. A. M. J.; Pastoreková, S.; Scozzafava, A.; Wouters, B. G.; Lambin, P. Imaging the hypoxia surrogate marker CA IX requires expression and catalytic activity for binding fluorescent sulfonamide inhibitors. Radiother. Oncol. 2007, 83, 367-373.

(25) Doss, M.; Kolb, H. C.; Walsh, J. C.; Mocharla, V. P.; Zhu, Z.; Haka, M.; Alpaugh, R. K.; Chen, D. Y. T.; Yu, J. Q. Biodistribution and Radiation Dosimetry of the Carbonic Anhydrase IX Imaging Agent [18 F]VM4-037 Determined from PET/CT Scans in Healthy Volunteers. Mol. Imaging Biol. 2014, 16, 739-746.

(26) Lau, J.; Liu, Z.; Lin, K.-S.; Pan, J.; Zhang, Z.; Vullo, D.; Supuran, C. T.; Perrin, D. M.; Bénard, F. Trimeric Radiofluorinated Sulfonamide Derivatives to Achieve In Vivo Selectivity for Carbonic Anhydrase IX-Targeted PET Imaging. J. Nucl. Med. 2015, 56, 14341440.

(27) Lau, J.; Zhang, Z.; Jenni, S.; Kuo, H.-T.; Liu, Z.; Vullo, D.; Supuran, C. T.; Lin, K.-S.; Bénard, F. PET imaging of carbonic anhydrase IX expression of HT-29 tumor xenograft mice with 68Galabeled benzenesulfonamides. Mol. Pharmaceutics 2016, 13, 11371146.

(28) Pan, J.; Lau, J.; Mesak, F.; Hundal, N.; Pourghiasian, M.; Liu, Z.; Bénard, F.; Dedhar, S.; Supuran, C. T.; Lin, K.-S. Synthesis and evaluation of 18F-labeled carbonic anhydrase IX inhibitors for imaging with positron emission tomography. J. Enzyme Inhib. Med. Chem. 2014, 29, 249-255.

(29) Day, J. A.; Cohen, S. M. Investigating the Selectivity of Metalloenzyme Inhibitors. J. Med. Chem. 2013, 56, 7997-8007.

(30) Peeters, S. J. A.; Dubois, L.; Lieuwes, N.; Laan, D.; Mooijer, M.; Schuit, R.; Vullo, D.; Supuran, C.; Eriksson, J.; Windhorst, A.; Lambin, P. [18F]VM4-037 MicroPET Imaging and Biodistribution of Two In Vivo CAIX-Expressing Tumor Models. Mol. Imaging Biol. 2015, 17, 615-619.

(31) Metwalli, A. R.; Turkbey, B.; McKinney, Y.; Weaver, J.; YaqubOgun, N.; Merino, M.; Lindenberg, M. L.; Linehan, W. M.; Choyke, P. L. Results of a phase II trial of novel carbonic anhydrase IX radiotracer 18F-VM4-037 in renal cell carcinoma. Presented at the 2014 Genitourinary Cancer Symposium, San Francisco, CA, USA, 2014.

(32) Turkbey, B.; Lindenberg, M. L.; Adler, S.; Kurdziel, K. A.; McKinney, Y. L.; Weaver, J.; Vocke, C. D.; Anver, M.; Bratslavsky, G.; Eclarinal, P.; Kwarteng, G.; Lin, F. I.; Yaqub-Ogun, N.; Merino, M. J.; Marston Linehan, W.; Choyke, P. L.; Metwalli, A. R. PET/CT imaging of renal cell carcinoma with 18F-VM4-037: a phase II pilot study. Abdom. Radiol. 2016, 41, 109-118.

(33) Velikyan, I. Prospective of (68)Ga-Radiopharmaceutical Development. Theranostics 2014, 4, 47-80.

(34) Ambrosini, V.; Tomassetti, P.; Franci, R.; Fanti, S. Imaging of NETs with PET radiopharmaceuticals. Q. J. Nucl. Med. Mol. Imaging 2010, 54, 16-23.

(35) Carter, N. D.; Heath, R.; Welty, R. J.; Hewe'It-Emmett, D.; Jeffery, S.; Shiels, A.; Tashian, R. E. Red Cells Genetically Deficient in Carbonic Anhydrase II Have Elevated Levels of a Carbonic Anhydrase Indistinguishable from Muscle CA IIIa. Ann. N. Y. Acad. Sci. 1984, 429, 284-286.

(36) Akurathi, V.; Dubois, L.; Celen, S.; Lieuwes, N. G.; Chitneni, S. K.; Cleynhens, B. J.; Innocenti, A.; Supuran, C. T.; Verbruggen, A. M.; Lambin, P.; Bormans, G. M. Development and biological evaluation of $99 \mathrm{mTc}$-sulfonamide derivatives for in vivo visualization of CA IX as surrogate tumor hypoxia markers. Eur. J. Med. Chem. 2014, 71, 374384.

(37) Akurathi, V.; Dubois, L.; Lieuwes, N. G.; Chitneni, S. K.; Cleynhens, B. J.; Vullo, D.; Supuran, C. T.; Verbruggen, A. M.; Lambin, P.; Bormans, G. M. Synthesis and biological evaluation of a $99 \mathrm{mTc}$-labelled sulfonamide conjugate for in vivo visualization of carbonic anhydrase IX expression in tumor hypoxia. Nucl. Med. Biol. 2010, 37, 557-564.

(38) Lopez, M.; Salmon, A. J.; Supuran, C. T.; Poulsen, S.-A. Carbonic Anhydrase Inhibitors Developed Through "Click Tailing". Curr. Pharm. Des. 2010, 16, 3277-3287.

(39) Lopez, M.; Drillaud, N.; Bornaghi, L. F.; Poulsen, S.-A. Synthesis of S-Glycosyl Primary Sulfonamides. J. Org. Chem. 2009, 74, 28112816.

(40) Salmon, A. J.; Williams, M. L.; Maresca, A.; Supuran, C. T.; Poulsen, S.-A. Synthesis of glycoconjugate carbonic anhydrase inhibitors by ruthenium-catalysed azide-alkyne 1,3-dipolar cycloaddition. Bioorg. Med. Chem. Lett. 2011, 21, 6058-6061.

(41) Rankin, G. M.; Vullo, D.; Supuran, C. T.; Poulsen, S.-A. Phosphate Chemical Probes Designed for Location Specific Inhibition of Intracellular Carbonic Anhydrases. J. Med. Chem. 2015, 58, 75807590.

(42) Moeker, J.; Mahon, B. P.; Bornaghi, L. F.; Vullo, D.; Supuran, C. T.; McKenna, R; Poulsen, S.-A. Structural Insights into Carbonic Anhydrase IX Isoform Specificity of Carbohydrate-Based Sulfamates. J. Med. Chem. 2014, 57, 8635-8645.

(43) Poulsen, S.-A. Carbonic anhydrase inhibition as a cancer therapy: a review of patent literature, $2007-2009$. Expert Opin. Ther. Pat. 2010, 20, 795-806.

(44) Price, E. W.; Orvig, C. Matching chelators to radiometals for radiopharmaceuticals. Chem. Soc. Rev. 2014, 43, 260-290.

(45) Mojtahedi, A.; Thamake, S.; Tworowska, I.; Ranganathan, D.; Delpassand, E. S. The value of (68)Ga-DOTATATE PET/CT in diagnosis and management of neuroendocrine tumors compared to current FDA approved imaging modalities: a review of literature. Am. J. Nucl. Med. Mol. Imaging 2014, 4, 426-434.

(46) Eder, M.; Neels, O.; Müller, M.; Bauder-Wüst, U.; Remde, Y.; Schäfer, M.; Hennrich, U.; Eisenhut, M.; Afshar-Oromieh, A.; Haberkorn, U.; Kopka, K. Novel Preclinical and Radiopharmaceutical Aspects of $[(68) \mathrm{Ga}] \mathrm{Ga}-\mathrm{PSMA}-\mathrm{HBED}-\mathrm{CC}$ : A New PET Tracer for Imaging of Prostate Cancer. Pharmaceuticals 2014, 7, 779-796.

(47) Meldal, M.; Tornøe, C. W. Cu-Catalyzed Azide-Alkyne Cycloaddition. Chem. Rev. 2008, 108, 2952-3015.

(48) Tron, G. C.; Pirali, T.; Billington, R. A.; Canonico, P. L.; Sorba, G.; Genazzani, A. A. Click chemistry reactions in medicinal chemistry: Applications of the 1,3-dipolar cycloaddition between azides and alkynes. Med. Res. Rev. 2008, 28, 278-308.

(49) Kadajii, V. G.; Betageri, G. V. Water Soluble Polymers for Pharmaceutical Applications. Polymers 2011, 3, 1972-2009.

(50) Knop, K.; Hoogenboom, R.; Fischer, D.; Schubert, U. S. Poly(ethylene glycol) in Drug Delivery: Pros and Cons as Well as Potential Alternatives. Angew. Chem., Int. Ed. 2010, 49, 6288-6308.

(51) Rami, M.; Cecchi, A.; Montero, J.-L.; Innocenti, A.; Vullo, D.; Scozzafava, A.; Winum, J.-Y.; Supuran, C. T. Carbonic Anhydrase Inhibitors: Design of Membrane-Impermeant Copper(II) Complexes of DTPA-, DOTA-, and TETA-Tailed Sulfonamides Targeting the Tumor-Associated Transmembrane Isoform IX. ChemMedChem 2008, 3, 1780-1788.

(52) Rami, M.; Montero, J.-L.; Dubois, L.; Lambin, P.; Scozzafava, A.; Winum, J.-Y.; Supuran, C. T. Carbonic anhydrase inhibitors: Gd(iii) complexes of DOTA- and TETA-sulfonamide conjugates targeting the tumor associated carbonic anhydrase isozymes IX and XII. New J. Chem. 2010, 34, 2139-2144.

(53) Wilkinson, B. L.; Innocenti, A.; Vullo, D.; Supuran, C. T.; Poulsen, S.-A. Inhibition of Carbonic Anhydrases with Glycosyltriazole Benzene Sulfonamides. J. Med. Chem. 2008, 51, 1945-1953.

(54) Hannant, J.; Hedley, J. H.; Pate, J.; Walli, A.; Farha Al-Said, S. A.; Galindo, M. A.; Connolly, B. A.; Horrocks, B. R.; Houlton, A.; Pike, 
A. R. Modification of DNA-templated conductive polymer nanowires via click chemistry. Chem. Commun. 2010, 46, 5870-5872.

(55) Barnett, D. J. Radiopharmaceutical compositions. WO 2012/ $013701 \mathrm{Al}, 2012$.

(56) Prasuhn, D. E., Jr.; Yeh, R. M.; Obenaus, A.; Manchester, M.; Finn, M. G. Viral MRI contrast agents: coordination of Gd by native virions and attachment of Gd complexes by azide-alkyne cycloaddition. Chem. Commun. 2007, 1269-1271.

(57) Supuran, C. T.; Scozzafava, A. Benzolamide is not a Membraneimpermeant Carbonic Anhydrase Inhibitor. J. Enzyme Inhib. Med. Chem. 2004, 19, 269-273.

(58) Khalifah, R. G. The Carbon Dioxide Hydration Activity of Carbonic Anhydrase: I. Stop-flow Kinetic Studies on the Native Human Isoenzymes B and C. J. Biol. Chem. 1971, 246, 2561-2573.

(59) Rami, M.; Dubois, L.; Parvathaneni, N.-K.; Alterio, V.; van Kuijk, S. J. A.; Monti, S. M.; Lambin, P.; De Simone, G.; Supuran, C. T.; Winum, J.-Y. Hypoxia-Targeting Carbonic Anhydrase IX Inhibitors by a New Series of Nitroimidazole-Sulfonamides/Sulfamides/ Sulfamates. J. Med. Chem. 2013, 56, 8512-8520.

(60) Dubois, L.; Peeters, S. G. J. A.; van Kuijk, S. J. A.; Yaromina, A.; Lieuwes, N. G.; Saraya, R.; Biemans, R.; Rami, M.; Parvathaneni, N. K.; Vullo, D.; Vooijs, M.; Supuran, C. T.; Winum, J.-Y.; Lambin, P. Targeting carbonic anhydrase IX by nitroimidazole based sulfamides enhances the therapeutic effect of tumor irradiation: A new concept of dual targeting drugs. Radiother. Oncol. 2013, 108, 523-528.

(61) Dubois, L.; Peeters, S.; Lieuwes, N. G.; Geusens, N.; Thiry, A.; Wigfield, S.; Carta, F.; McIntyre, A.; Scozzafava, A.; Dogné, J.-M.; Supuran, C. T.; Harris, A. L.; Masereel, B.; Lambin, P. Specific inhibition of carbonic anhydrase IX activity enhances the in vivo therapeutic effect of tumor irradiation. Radiother. Oncol. 2011, 99, 424-431.

(62) Lam, C. F. C.; Giddens, A. C.; Chand, N.; Webb, V. L.; Copp, B. R. Semi-synthesis of bioactive fluorescent analogues of the cytotoxic marine alkaloid discorhabdin C. Tetrahedron 2012, 68, 3187-3194.

(63) Bakleh, M. E.; Sol, V.; Estieu-Gionnet, K.; Granet, R.; Déléris, G.; Krausz, P. An efficient route to VEGF-like peptide porphyrin conjugates via microwave-assisted 'click-chemistry'. Tetrahedron 2009, $65,7385-7392$.

(64) Goswami, L. N.; Houston, Z. H.; Sarma, S. J.; Jalisatgi, S. S.; Hawthorne, M. F. Efficient synthesis of diverse heterobifunctionalized clickable oligo(ethylene glycol) linkers: potential applications in bioconjugation and targeted drug delivery. Org. Biomol. Chem. 2013, $11,1116-1126$.

(65) Raghunand, N.; Guntle, G. P.; Gokhale, V.; Nichol, G. S.; Mash, E. A.; Jagadish, B. Design, Synthesis, and Evaluation of 1,4,7,10Tetraazacyclododecane-1,4,7-triacetic Acid Derived, Redox-Sensitive Contrast Agents for Magnetic Resonance Imaging. J. Med. Chem. 2010, 53, 6747-6757.

(66) Kale, R. R.; Clancy, C. M.; Vermillion, R. M.; Johnson, E. A.; Iyer, S. S. Synthesis of soluble multivalent glycoconjugates that target the Hc region of botulinum neurotoxin A. Bioorg. Med. Chem. Lett. 2007, 17, 2459-2464.

(67) Ščasnár, V.; van Lier, J. E. The use of SEP-PAK Sl cartridges for the preparation of gallium chloride from the citrate solution. Eur. J. Nucl. Med. 1993, 20, 273.

(68) Winum, J.-Y.; Vullo, D.; Casini, A.; Montero, J.-L.; Scozzafava, A.; Supuran, C. T. Carbonic Anhydrase Inhibitors. Inhibition of Cytosolic Isozymes I and II and Transmembrane, Tumor-Associated Isozyme IX with Sulfamates Including EMATE Also Acting as Steroid Sulfatase Inhibitors. J. Med. Chem. 2003, 46, 2197-2204.

(69) Vullo, D.; Innocenti, A.; Nishimori, I.; Pastorek, J. r.; Scozzafava, A.; Pastoreková, S.; Supuran, C. T. Carbonic anhydrase inhibitors. Inhibition of the transmembrane isozyme XII with sulfonamides-a new target for the design of antitumor and antiglaucoma drugs? Bioorg. Med. Chem. Lett. 2005, 15, 963-969. 